\title{
Zinc surface complexes on birnessite: A density functional theory study
}

\author{
Kideok D. Kwon ${ }^{1 *}$, Keith Refson ${ }^{2}$, and Garrison Sposito ${ }^{1}$ \\ ${ }^{1}$ Geochemistry Department, Earth Sciences Division, Lawrence Berkeley National Laboratory, \\ Berkeley, CA 94720 \\ ${ }^{2}$ STFC Rutherford Appleton Laboratory, Didcot, Oxfordshire OX11 0QX, United Kingdom \\ *Corresponding author: kkwon@nature.berkeley.edu
}




\section{Abstract}

Biogeochemical cycling of zinc is strongly influenced by sorption on birnessite minerals (layertype $\mathrm{MnO}_{2}$ ), which are found in diverse terrestrial and aquatic environments. Zinc has been observed to form both tetrahedral $\left(\mathrm{Zn}^{\mathrm{IV}}\right)$ and octahedral $\left(\mathrm{Zn}^{\mathrm{VI}}\right)$ triple-corner-sharing surface complexes (TCS) at Mn(IV) vacancy sites in hexagonal birnessite. The octahedral complex is expected to be similar to that of $\mathrm{Zn}$ in the $\mathrm{Mn}$ oxide mineral, chalcophanite $\left(\mathrm{ZnMn}_{3} \mathrm{O}_{7} \cdot 3 \mathrm{H}_{2} \mathrm{O}\right)$, but the reason for the occurrence of the four-coordinate $\mathrm{Zn}$ surface species remains unclear. We address this issue computationally using spin-polarized Density Functional Theory (DFT) to examine the $\mathrm{Zn}^{\mathrm{IV}}$-TCS and $\mathrm{Zn}{ }^{\mathrm{VI}}$-TCS species. Structural parameters obtained by DFT geometry optimization were in excellent agreement with available experimental data on $\mathrm{Zn}$-birnessites. Total energy, magnetic moments, and electron-overlap populations obtained by DFT for isolated $\mathrm{Zn}^{\text {IV }}$-TCS revealed that this species is stable in birnessite without a need for Mn(III) substitution in the octahedral sheet and that it is more effective in reducing undersaturation of surface $\mathrm{O}$ at a $\mathrm{Mn}$ vacancy than is $\mathrm{Zn}^{\mathrm{VI}}$-TCS. Comparison between geometry-optimized $\mathrm{ZnMn}_{3} \mathrm{O}_{7} \cdot 3 \mathrm{H}_{2} \mathrm{O}$ (chalcophanite) and the hypothetical monohydrate mineral, $\mathrm{ZnMn}_{3} \mathrm{O}_{7} \cdot \mathrm{H}_{2} \mathrm{O}$, which contains only tetrahedral $\mathrm{Zn}$, showed that the hydration state of $\mathrm{Zn}$ significantly affects birnessite structural stability. Finally, our study also revealed that, relative to their positions in an ideal vacancy-free $\mathrm{MnO}_{2}, \mathrm{Mn}$ nearest to $\mathrm{Zn}$ in a TCS surface complex move toward the vacancy by $0.08-0.11 \AA$, while surface $\mathrm{O}$ bordering the vacancy move away from it by $0.16-0.21 \AA$, in agreement with recent X-ray absorption spectroscopic analyses. 


\section{INTRODUCTION}

Birnessite (layer-type $\mathrm{MnO}_{2}$ ), produced mainly by bacteria and fungi, is a ubiquitous environmental nanoparticle participating in important geochemical processes, particularly metal scavenging (Tebo et al., 2004; Tonkin et al., 2004; Toner et al., 2006, Manceau et al., 2007; Miyata et al., 2007). Among the trace metals of major interest, $\mathrm{Zn}$ appears to be influenced strongly in its biogeochemical cycling by sorption on birnessite minerals found in soils, aquifers, streams, and wetlands (Toner et al., 2006). Detailed molecular-scale studies of sorbed $\mathrm{Zn}^{2+}$ species have been published for chemically- and microbially-synthesized birnessite (Manceau et al., 2002; Toner et al., 2006), natural soil and marine birnessite (Marcus et al., 2004; Manceau et al., 2007), and Zn-Mn coprecipitates on plant roots (Lanson et al., 2008). These studies reveal that $\mathrm{Zn}^{2+}$ binds to $\mathrm{Mn}(\mathrm{IV})$ vacancy sites in hexagonal birnessite, forming triple-corner-sharing (TCS) inner-sphere surface complexes with the three surface O surrounding a vacancy. This mode of binding is similar to that observed in the mineral, chalcophanite $\left[\mathrm{ZnMn}_{3} \mathrm{O}_{7} \cdot 3 \mathrm{H}_{2} \mathrm{O}\right.$, Post and Appleman (1988)], in which $\mathrm{Zn}$ is in octahedral coordination with three surface $\mathrm{O}$ around a $\mathrm{Mn}(\mathrm{IV})$ vacancy as well as three $\mathrm{O}$ from three structural $\mathrm{H}_{2} \mathrm{O}$ (Fig. 1). However, the local coordination environment of $\mathrm{Zn}$ sorbed by birnessite does not merely replicate that in chalcophanite. Manceau et al. (2002) have shown that, in addition to octahedrally-coordinated $\mathrm{Zn}\left(\mathrm{Zn}^{\mathrm{VI}}-\mathrm{TCS}\right)$, tetrahedrally-coordinated $\mathrm{Zn}\left(\mathrm{Zn}^{\mathrm{IV}}-\mathrm{TCS}\right)$ bound to three surface $\mathrm{O}$ and one $\mathrm{H}_{2} \mathrm{O}$ can exist in Zn-birnessite, preferentially at low surface coverage of Zn. Structural parameters reported for their sample $\mathrm{ZnBi}$, i.e., nearest-neighbor distances, $d(\mathrm{Zn}-\mathrm{O})=1.97 \AA$ and $d(\mathrm{Zn}-$ $\left.\mathrm{Mn}_{1 \mathrm{st}}\right)=3.35 \AA$, and a $\mathrm{Zn}-\mathrm{O}$ coordination number near 4 , are representative of the $\mathrm{Zn}^{\mathrm{IV}}-\mathrm{TCS}$ species (Table 1). 
Among the studies of $\mathrm{Zn}$ sorbed on birnessite summarized in Table 1 none describes a fully-characterized reference sample suitable for use as a unique $\mathrm{Zn}^{\mathrm{IV}}$-TCS end-member. The synthetic birnessite for which Manceau et al. (2002) first reported the presence of $\mathrm{Zn}^{\mathrm{IV}}$-TCS contained about $13 \mathrm{~mol} \% \mathrm{Mn}(\mathrm{III})$ substituted for Mn(IV) in the octahedral sheet (Lanson et al., 2002), and the formation of $\mathrm{Zn}^{\mathrm{IV}}$-TCS was accordingly conjectured to result from the presence of this structural Mn(III) (Manceau et al., 2002). Similarly, the natural marine Zn-birnessite sample investigated by Marcus et al. (2004), whose octahedrally-coordinated $\mathrm{Zn}$ content is at most 7 mol \%, was reported to have about $10 \mathrm{~mol} \% \mathrm{Mn}(\mathrm{III})$ substituted in the octahedral sheet. However, other birnessite samples shown to contain the $\mathrm{Zn}^{\mathrm{IV}}$-TCS species comprise sheets of octahedra with only Mn(IV) present [sediment birnessite, Isaure et al. (2005); bacteriogenic birnessite and $\delta-\mathrm{MnO}_{2}$, Toner et al. (2006); quartz-coating birnessite, Manceau et al. (2007); plant-root Zn-Mn coprecipitate, Lanson et al. (2008)]. Therefore, it does not seem necessary to connect the existence of $\mathrm{Zn}^{\mathrm{IV}}$-TCS uniquely to the presence of $\mathrm{Mn}$ (III) substituted in the octahedral sheet and the fundamental basis for the occurrence of the four-coordinate surface species remains unclear.

In the present paper, we address this conundrum theoretically using geometry optimizations based on Density Functional Theory (DFT) to examine the $\mathrm{Zn}^{\mathrm{IV}}$-TCS and $\mathrm{Zn}^{\mathrm{VI}}$ TCS species in hexagonal layer-type $\mathrm{Mn}(\mathrm{IV}) \mathrm{O}_{2}$. First-principles simulations based on DFT can describe chemical bonding features of condensed phases, such as minerals, to a high degree of accuracy without adjustable parameters (Koch and Holthausen, 2002; Cramer, 2003; Martin, 2004; Kohanoff, 2006). These simulations thus complement experimental data by exploring electronic and structural details of complex systems which experimental techniques may not 
fully elucidate. In the present case, hydrated $\mathrm{Zn}$ surface complexes were geometry-optimized via total energy and force minimization to provide detailed structural and electronic information about their stable groundstates. Density functional theory using plane-wave basis sets and periodic boundary conditions subject to Bloch's Theorem (Payne et al., 1992; Segall et al., 2002) is especially well-positioned to achieve accurate results for layer-type minerals through careful convergence tests performed by systematically varying the DFT components [e.g., kinetic energy cutoff, Brillouin zone sampling, and supercell size (Mattsson et al., 2005)]. Furthermore, since a plane-wave basis set treats empty space the same as it does the atoms on a lattice, defect structures such as $\mathrm{Mn}(\mathrm{IV})$ vacancies are described without structural bias.

To validate the quality of our DFT calculations, as well as examine the stability of hexagonal $\mathrm{Zn}-\mathrm{Mn}(\mathrm{IV}) \mathrm{O}_{2}$, we first geometry-optimized the structure of chalcophanite $\left(\mathrm{ZnMn}_{3} \mathrm{O}_{7} \cdot 3 \mathrm{H}_{2} \mathrm{O}\right)$ and compared our results to available experimental data. Then an isolated $\mathrm{Zn}^{\mathrm{IV}}$-TCS complex at a Mn(IV) vacancy was examined as a $\mathrm{Zn}^{\mathrm{IV}}$-TCS end-member. Lastly, doubly-occupied $\mathrm{Zn}$-TCS complexes (i.e., $\mathrm{Zn}^{\mathrm{IV}}-\mathrm{TCS}+\mathrm{Zn}^{\mathrm{IV}}-\mathrm{TCS} ; \mathrm{Zn}^{\mathrm{VI}}-\mathrm{TCS}+\mathrm{Zn}^{\mathrm{VI}}-\mathrm{TCS} ; \mathrm{Zn}^{\mathrm{IV}}$ $\mathrm{TCS}+\mathrm{Zn}{ }^{\mathrm{VI}}$-TCS) were considered by analogy with the double $\mathrm{Zn}$ occupancy found in chalcophanite. Structural distortion of a Mn(IV) vacancy site was also investigated to understand why interatomic distances determined by X-ray absorption spectroscopy often are not compatible with those determined by X-ray diffraction, with reconciliation between the two then requiring ad hoc displacement of the surface O positions around a vacancy (Manceau et al., 2002; Villalobos et al., 2005; Lanson et al., 2008).

\section{COMPUTATIONAL DETAILS}




\subsection{Spin-polarized plane-wave DFT}

All DFT optimizations were performed with the CASTEP code (Clark et al., 2005), which implements DFT in a plane-wave basis set to represent wavefunctions and uses ultrasoft pseudopotentials to replace strong coulomb potentials between atomic nuclei and core electrons with weak effective potentials, thus dramatically reducing the number of plane waves required to represent wavefunctions. Under standard approximations to account for electron exchange and correlation, eigenstates and eigenvalues of the Kohn-Sham Schrödinger equations (Kohn and Sham, 1965) were solved via efficient self-consistent iterative methods including density mixing (Kresse and Furthmüller, 1996). The CASTEP code has proven to be of very high accuracy in condensed matter studies (Milman et al., 2000), approaching the accuracy of all-electron (AE) methods, and of high efficiency in large-scale calculations such as solid-state defect studies (Probert and Payne, 2003).

Electron exchange and correlation were treated under the generalized gradient approximation (GGA) using Perdew, Burke, and Ernzerhof (PBE) functionals (Perdew et al., 1996). Ultrasoft pseudopotentials (Vanderbilt, 1990) were constructed for Mn and O ions using the on-the-fly pseudopotential generator implemented in CASTEP with the valence-electron configurations $3 s^{2} 3 p^{6} 3 d^{5} 4 s^{2}$ for $\mathrm{Mn}$ and $2 s^{2} 2 p^{4}$ for $\mathrm{O}$. The core radius for Mn was $2.3 a_{0}\left(a_{0}=\right.$ $0.52918 \AA$ is the Bohr radius) while that of O was $1.3 a_{0}$. The $\mathrm{q}_{\mathrm{c}}$ for KE optimization were set at 5.5 and $6 a_{0}^{-1}$ for Mn and O, respectively. Tests of the ultrasoft pseudopotentials at a $500 \mathrm{eV}$ cutoff energy reproduced structure and energy data of $\mathrm{MnO}$ as calculated with AE methods (Pask et al., 2001). For $\mathrm{H}$ and $\mathrm{Zn}\left(3 d^{10} 4 s^{2}\right.$, core radius $\left.=2.0 a_{0}\right)$, Vanderbilt ultrasoft pseudopotentials in the CASTEP library were used (version 7.3.2). Test runs on $\mathrm{ZnO}$ in the wurtzite structure and 
aqueous $\mathrm{Zn}$ in the form of $\left[\mathrm{Zn}\left(\mathrm{H}_{2} \mathrm{O}\right)_{4}\right]^{2+} \cdot\left(\mathrm{H}_{2} \mathrm{O}\right)_{2}$ and $\left[\mathrm{Zn}\left(\mathrm{H}_{2} \mathrm{O}\right)_{6}\right]^{2+}$ also reproduced the results of AE calculations (Dudev and Lim, 2000; Zhao et al., 2006).

The electrons in Mn ions are spin-polarized (i.e., unequal numbers of spin-up and spin-down electrons occupy the orbitals), leading to a net magnetic moment and thus magnetic coupling between Mn ions. Accordingly, to reproduce accurately the structural, electronic, and magnetic properties of Mn oxides, a spin-polarization treatment is essential in performing DFT calculations (Balachandran et al., 2003; Pask et al., 2001; Singh, 1997), i.e., electron densities are calculated separately for spin-up and spin-down orientations. All calculations in the present study were performed with spin polarization and exhibited ferromagnetic ordering among Mn ions within a layer. [The triangular Mn lattice does not allow an antiferromagnetic spin order because of frustration (Moessner and Ramirez, 2006), resulting in the stabilization of the otherwise higher energy ferromagnetic ordering.] Calculations for vacancy-free $\mathrm{MnO}_{2}$ showed that omitting spin polarization underestimated important interatomic distances as much as by 0.1 $\AA$ as compared to the corresponding spin-polarized calculations, a result which is consistent with those of Mishra and Ceder (1999) as well as with available experimental data. Antiferromagnetic alignment between octahedral sheets with ferromagnetic ordering in each sheet was also examined as an alternative, but the total energy difference found was less than the energy variability in calculations using the chosen approach $(0.005 \mathrm{eV} / \AA)$.

\subsection{Model structures}

The hexagonal unit cell reported by Post and Appleman (1988) was used as a starting structure for geometry optimization of chalcophanite $\left(\mathrm{ZnMn}_{3} \mathrm{O}_{7} \cdot 3 \mathrm{H}_{2} \mathrm{O}\right)$. For the $\mathrm{Zn}$-TCS species 
in birnessite, a model hexagonal $\mathrm{Mn}(\mathrm{IV}) \mathrm{O}_{2}$ with $\mathrm{Mn}(\mathrm{IV})$ vacancies charge-compensated by protons was developed as follows: First, vacancy-free $\mathrm{Mn}(\mathrm{IV}) \mathrm{O}_{2}$ was geometry-optimized based on the $\mathrm{Mn}$ and $\mathrm{O}$ atomic coordinates of microcrystalline layer-type $\mathrm{K}-\mathrm{Mn}(\mathrm{IV}) \mathrm{O}_{2}$ (Gaillot et al., 2003). This well-characterized $\mathrm{Mn}$ oxide has space group $\mathrm{P}_{3} / m m c$ and a two-layer unit cell with hexagonal lattice parameters $a=2.840 \AA$ and $c=14.031 \AA$. Second, a protonated defect was introduced into a 4 x 4 x 1 supercell of vacancy-free $\mathrm{MnO}_{2}$ by coordination of one Mn vacancy at the center of the supercell to four $\mathrm{H}$ bound to the "dangling" O ions bordering the vacancy. This supercell corresponds to the structural formula, $\mathrm{H}_{0.13}\left[\mathrm{Mn}_{0.967} \square_{0.033}\right] \mathrm{O}_{2}$, where $\square$ represents a vacancy. The protonated $4 \times 4 \times 1 \mathrm{MnO}_{2}$ supercell was geometry-optimized using a $500 \mathrm{eV}$ cut-off energy and a 2 x 2 x $1 k$-point grid for the first Brillouin zone (Monkhorst and Pack, 1976) after fixing the three unit-cell angles $\left(90^{\circ}, 90^{\circ}\right.$, and $\left.120^{\circ}\right)$ and the $c$ lattice parameter (14.001 $\AA$, as obtained for the geometry-optimized vacancy-free $\mathrm{MnO}_{2}$ ), but with the $a$ and $b$ lattice parameters and all internal ionic positions relaxed under $0.01 \mathrm{eV} / \AA$ and $0.02 \mathrm{GPa}$ tolerance for the maximum force and stress, respectively, along any Cartesian component. Lastly, in the geometry-optimized protonated $\mathrm{MnO}_{2}$ supercell (i.e., $11.587 \AA$ x $11.587 \AA$ x $14.001 \AA$ ), either two or four $\mathrm{H}$ at the vacancy site were replaced with either one or two $\mathrm{Zn}^{2+}$ ions coordinated to $\mathrm{H}_{2} \mathrm{O}$ molecules to give the composition $\mathrm{Zn}_{\mathrm{x}}\left(\mathrm{H}_{2} \mathrm{O}\right)_{\mathrm{n}} \cdot \mathrm{H}_{4-2 \mathrm{x}}\left[\mathrm{Mn}_{31} \square\right] \mathrm{O}_{64}(\mathrm{x}=1$ or 2 , $\mathrm{n}$ $=1$ or 3) for singly-occupied $(\mathrm{x}=1)$, or doubly-occupied $(\mathrm{x}=2), \mathrm{Zn}^{\mathrm{IV}}-\mathrm{TCS}(\mathrm{n}=1)$ or $\mathrm{Zn}^{\mathrm{VI}}-\mathrm{TCS}$ $(\mathrm{n}=3)$. Thus the charge deficit created by a Mn(IV) vacancy was compensated either by one $\mathrm{Zn}$ TCS species and two H on the other side of the sheet or by two Zn-TCS species on both sides.

\subsection{Geometry optimizations}


Geometry optimizations were performed without imposed symmetry using the Broyden, Fletcher, Goldfarb, Shanno (BFGS) procedure (Pfrommer et al., 1997). [The damped molecular dynamics method (Probert, 2003) was also explored, but significant improvement was not observed as compared to the BFGS method.] The energy tolerance was $5 \times 10^{-6} \mathrm{eV} /$ atom, and the maximum tolerance for force and for atom displacement along any Cartesian component was $0.03 \mathrm{eV} / \AA$ and $0.0005 \AA$, respectively. In an effort to obtain an accurate force, low tolerance was used for the self-consistent-field electronic energy $\left(10^{-8} \mathrm{eV} /\right.$ atom $)$.

In the geometry optimization of $\mathrm{ZnMn}_{3} \mathrm{O}_{7} \cdot 3 \mathrm{H}_{2} \mathrm{O}$, all internal atomic positions and lattice parameters were relaxed on a 4 x 4 x $1 k$-point grid (i.e., eight $k$-points) for the first Brillouin zone with a $500 \mathrm{eV}$ cut-off energy for the ultrasoft pseudopotentials. Convergence tests performed for the $4 \times 4 \times 1 k$-point grid showed very high convergence of force $(0.001 \mathrm{eV} / \AA$ or better). In addition to the total energy and force, the CASTEP code calculates the stress tensor of a model system during geometry optimization. The root-mean-square (RMS) value of the calculated stress tensor can be used to evaluate the quality of a geometry optimization, in particular for supercells, because the ideal value for a groundstate crystal geometry-optimized under zero pressure should be close to $0 \mathrm{GPa}$. In our optimized chalcophanite model, the RMS stress was only $0.002 \mathrm{GPa}$.

For $\mathrm{Zn}-\mathrm{TCS}-\mathrm{MnO}_{2}$, all internal ionic positions in the $4 \times 4 \times 1$ supercell were relaxed with fixed lattice parameters (i.e., $11.587 \AA$ x $11.587 \AA$ x $14.001 \AA$ and $90^{\circ}, 90^{\circ}$, and $120^{\circ}$ ). Relaxation of the lattice parameters did not affect the precision of our results in terms of the interatomic distances: the RMS stress of the optimized $\mathrm{Zn}^{\mathrm{IV}}-\mathrm{TCS}+\mathrm{Zn}^{\mathrm{VI}}-\mathrm{TCS} \mathrm{MnO}_{2}$ supercell was $0.253 \mathrm{GPa}$, and further relaxation of the lattice parameters to yield a RMS stress of 0.058 
GPa (i.e., $11.570 \AA$ x $11.570 \AA$ x $14.131 \AA$ and $90^{\circ}, 90^{\circ}$, and $120^{\circ}$ ) showed a tendency to increase the interatomic distances by no more than $0.005 \AA$. The RMS stress of the optimized $\mathrm{Zn}^{\mathrm{IV}}$-TCS- $\mathrm{MnO}_{2}$ model was $0.158 \mathrm{GPa}$. For the first Brillouin zone of the $\mathrm{Zn}-\mathrm{TCS}-\mathrm{MnO}_{2}$, a $2 \mathrm{x}$ $2 \times 2 k$-point grid (i.e., four $k$-points) was used without offset of the grid origin. Convergence tests performed for the $2 \times 2 \times 2 k$-point grid with a $500 \mathrm{eV}$ cut-off energy showed very high convergence of force $(0.005 \mathrm{eV} / \AA \AA$ or better $)$.

In an insufficiently large supercell, interactions between a $\mathrm{Zn}$ ion and its images in neighboring periodic cells could result in significant errors in the calculated total energy and force, and hence inaccurate geometry-optimized isolated Zn-TCS structures. To estimate the influence of $\mathrm{MnO}_{2}$ supercell size, geometry-optimized distances between $\mathrm{Zn}$ and unsaturated surface $\mathrm{O}\left(\mathrm{Zn}-\mathrm{O}_{2 \mathrm{Mn}}\right)$ were compared among the $\mathrm{Zn}-\mathrm{TCS}-\mathrm{MnO}_{2}$ supercells (without $\left.\mathrm{H}_{2} \mathrm{O}\right), 2$ × 2 x 1 (i.e., $5.793 \AA$ x $5.793 \AA$ x $14.001 \AA$ with $7 \mathrm{Mn}$ and $16 \mathrm{O}$ atoms), 4 x 4 x 1 (i.e., $11.587 \AA$ x $11.587 \AA \mathrm{x} 14.001 \AA$ with $31 \mathrm{Mn}$ and $64 \mathrm{O}$ atoms), and 6 x 6 x 1 (i.e., $17.380 \AA \mathrm{x} 17.380 \AA \mathrm{x}$ $14.001 \AA$ with $71 \mathrm{Mn}$ and $144 \mathrm{O}$ atoms). During these geometry optimizations, only the $\mathrm{Zn}$ position was relaxed, and all $\mathrm{Mn}$ and $\mathrm{O}$ positions were fixed based on the vacancy-free $\mathrm{MnO}_{2}$ structure with the same plane-wave cut-off energy $(500 \mathrm{eV})$ and the equivalent $k$-point grid density (e.g., 4 × 4 × 2 -point grid for the $2 \times 2 \times 1$ supercell). The $\mathrm{Zn}-\mathrm{O}$ distances found in these tests were $1.830 \AA, 1.837 \AA$, and $1.839 \AA$ for the $2 \times 2 \times 1,4 \times 4 \times 1$, and 6 × 6 x 1 supercells, respectively. Because the $\mathrm{Zn}-\mathrm{O}$ distance tends to converge well for the $4 \times 4 \times 1$ supercell, it was regarded sufficiently large to minimize the unwanted interactions between $\mathrm{Zn}-\mathrm{TCS}-\mathrm{MnO}_{2}$ cells.

\subsection{Magnetic moments and electron overlap population analysis}


Determining the oxidation states of $\mathrm{Mn}$ ions in birnessites remains an important research challenge (Kim et al., 1999; Manceau et al., 2002; Gaillot et al., 2003). Bond valence sums (Manceau et al., 2002) associated with X-ray diffraction modeling (Villalobos et al., 2006) provide semi-quantitative values, but magnetic moments or orbital-projected density of states in conjunction with crystal-field theory can give better information. For example, because the magnetic moments based on Hund's rule for isolated high-spin $\mathrm{Mn}(\mathrm{IV})$ and $\mathrm{Mn}(\mathrm{II})$ are $3 \mu_{B}$ and $5 \mu_{B}$, respectively $\left(\mu_{B}=9.274 \times 10^{-24} \mathrm{~J} \mathrm{~T}^{-1}\right.$ is the Bohr magneton), magnetic moments can indicate the oxidation numbers of Mn ions. Magnetic moments were calculated to identify the oxidation states of $\mathrm{Mn}$ in chalcophanite and in the $\mathrm{Zn}-\mathrm{TCS}-\mathrm{MnO}_{2}$ models through electron population analysis as implemented in CASTEP (Segall et al., 1996). Because unsaturated surface $\mathrm{O}$ ions of metal oxides show a large induction effect on spin polarization as compared to saturated O (Cline et al., 2000; Gallego et al., 2005), the spin states of O ions were analyzed to determine the relative bonding saturation of $\mathrm{O}$ near a Mn vacancy in $\mathrm{Zn}^{\mathrm{IV}}-\mathrm{TCS}$ vs. $\mathrm{Zn}{ }^{\mathrm{VI}}-\mathrm{TCS}$. Population analysis, in which plane-wave eigenfunctions are projected on to pseudo-atomic basis sets using the Mulliken formalism (Mulliken, 1955), also provides the number of electrons overlapped between ions, allowing correlation of the overlap population with the bond strength (Segall et al., 1996). Thus the overlap population between $\mathrm{Zn}$ and $\mathrm{O}$ was analyzed to evaluate a relative bond strength for $\mathrm{Zn}^{\mathrm{IV}}-\mathrm{TCS}$ vs. $\mathrm{Zn}^{\mathrm{VI}}$-TCS. The difference between the plane-wave eigenfunctions and the projected orbitals, which represents the incompleteness of the Mulliken analysis, was only 0.20 to $0.22 \%$.

\section{RESULTS AND DISCUSSION}




\section{1. $\mathrm{ZnMn}_{3} \mathrm{O}_{7} \cdot 3 \mathrm{H}_{2} \mathrm{O}$}

\subsubsection{Geometry-optimized structure}

Negligible differences were found between the calculated DFT and experimental atomic coordinates for chalcophanite, except for the structural $\mathrm{H}_{2} \mathrm{O}$ molecules (Table 2). However, the DFT-calculated distance between $\mathrm{Zn}$ and the nearest $\mathrm{Mn}$ in an adjacent sheet was $5.32 \AA$, which is much longer than the experimental value of $5.14 \AA$. Constrained geometry optimization performed with the $c$ parameter fixed at the XRD value (i.e., relaxation of all ionic positions, angles, and lattice parameters except for $c=20.794 \AA$ ) decreased the calculated distance to 5.18 $\AA$ without significant changes in the other interatomic distances. Therefore, the larger $c$ parameter predicted by the fully-relaxed $\mathrm{ZnMn}_{3} \mathrm{O}_{7} \cdot 3 \mathrm{H}_{2} \mathrm{O}$ optimization can be attributed simply to overestimation of the interlayer spacing between octahedral sheets by DFT/GGA.

Structural parameters describing the local $\mathrm{Zn}$ coordination environment were in excellent agreement with experiment. For example, the DFT bond length between $\mathrm{Zn}$ and surface $\mathrm{O}[d(\mathrm{Zn}-$ $\mathrm{O}_{2 \mathrm{Mn}}$ ), where $\mathrm{O}_{2 \mathrm{Mn}}$ is $\mathrm{O}$ coordinated with two $\mathrm{Mn}$ ] was $2.07 \AA$ (Fig. 1a) as compared to experimental values of $2.07 \AA$ (XRD, Post and Appleman, 1988) and $2.04 \AA$ (EXAFS, Manceau et al., 2002), while the DFT distance between $\mathrm{Zn}$ and the $\mathrm{O}$ of $\mathrm{H}_{2} \mathrm{O}\left[d\left(\mathrm{Zn}-\mathrm{O}\left(\mathrm{H}_{2} \mathrm{O}\right)\right)\right]$ was slightly larger $(2.24 \AA)$ than the corresponding XRD $(2.14 \AA)$ and EXAFS $(2.16 \AA)$ values. The DFT distance between $\mathrm{Zn}$ and the nearest $\mathrm{Mn}\left[d\left(\mathrm{Zn}-\mathrm{Mn}_{1 \mathrm{st}}\right)\right]$ was $3.51-3.52 \AA$ (Fig. 1b), which is consistent with the results of XRD $(3.49-3.50 \AA)$ and EXAFS $(3.52 \AA)$ measurements.

According to the results of our optimization, structural $\mathrm{H}_{2} \mathrm{O}$ in chalcophanite are oriented such that one $\mathrm{H}(\mathrm{H} 1)$ points toward an adjacent sheet while the other $\mathrm{H}(\mathrm{H} 2)$ forms a H-bond with a $\mathrm{H}_{2} \mathrm{O}$ hydrating a neighboring $\mathrm{Zn}$ (Fig. 1a). The DFT-calculated H-bond distance between 
$\mathrm{H} 1$ and $\mathrm{O}_{2 \mathrm{Mn}}$ was $2.19 \AA$ and that between $\mathrm{H} 1$ and $\mathrm{O}_{3 \mathrm{Mn}}$ was 2.24 to $2.49 \AA$. The H-bond distance between $\mathrm{H} 2$ and $\mathrm{O}$ of $\mathrm{H}_{2} \mathrm{O}$ coordinated to a neighboring $\mathrm{Zn}$ was $1.80 \AA$. Thus the Hbond distances between $\mathrm{H}_{2} \mathrm{O}$ molecules hydrating neighboring $\mathrm{Zn}$ are much shorter than those with the octahedral sheet, as also found by Post and Appleman (1988) [H1 ... $\mathrm{O}_{2 \mathrm{Mn}}: 2.11 \AA$; $\left.\mathrm{H} 1 \ldots \mathrm{O}_{3 \mathrm{Mn}}: 2.19-2.41 \AA ; \mathrm{H} 2 \ldots \mathrm{O}\left(\mathrm{H}_{2} \mathrm{O}\right): 1.98 \AA\right]$ using a modified-electron gas approach (Cohen and Gordon, 1976) constrained by the fixed chalcophanite structure as obtained by XRD refinement. Although the DFT-calculated $\mathrm{H}$-bond distance between $\mathrm{H}_{2} \mathrm{O}$ molecules is much shorter than that calculated by Post and Appleman (1988), the calculated distance between $\mathrm{O}$ of the H-bonded $\mathrm{H}_{2} \mathrm{O}$ molecules $(2.76 \AA)$ is very close to their XRD result $(2.77 \AA)$.

\subsubsection{Stabilizing effect of intermolecular H-bonds}

The effects of intermolecular $\mathrm{H}_{2} \mathrm{O}-\mathrm{H}_{2} \mathrm{O}$ H-bonds of $\mathrm{Zn}$ complexes on chalcophanite stability was examined by comparison of the geometry-optimized structures of $\mathrm{ZnMn}_{3} \mathrm{O}_{7} \cdot 3 \mathrm{H}_{2} \mathrm{O}$ and a hypothetical monohydrate, $\mathrm{ZnMn}_{3} \mathrm{O}_{7} \cdot \mathrm{H}_{2} \mathrm{O}$, which contains tetrahedrally-coordinated $\mathrm{Zn}$ created by removal of two $\mathrm{H}_{2} \mathrm{O}$ in the trihydrate $\mathrm{ZnMn}_{3} \mathrm{O}_{7} \cdot 3 \mathrm{H}_{2} \mathrm{O}$ and, therefore, has no H-bonds between neighboring $\mathrm{Zn}$ complexes. To reduce computation time, a rhombohedral primitive cell of chalcophanite was fully geometry-optimized without imposed symmetry instead of a hexagonal unit cell (e.g., $18 \mathrm{Mn}$ in a hexagonal cell vs. $6 \mathrm{Mn}$ in a rhombohedral cell). The optimized cell parameters of $\mathrm{ZnMn}_{3} \mathrm{O}_{7} \cdot 3 \mathrm{H}_{2} \mathrm{O}$ were $a=b=c=8.361 \AA$ and $\alpha=\beta=\gamma=54.08^{\circ}$, which are equivalent to the hexagonal parameters $(a=b=7.602 \AA, c=21.349 \AA$, and $\alpha=90.0$, $\beta=90.0, \gamma=120.0^{\circ}$ ). The hypothetical $\mathrm{ZnMn}_{3} \mathrm{O}_{7} \cdot \mathrm{H}_{2} \mathrm{O}$ in a rhombohedral primitive cell was fully geometry-optimized without imposing symmetry, yielding the cell parameters $a=8.891, b=$ 
$8.160, c=8.020 \AA$ and $\alpha=56.47^{\circ}, \beta=53.54^{\circ}, \gamma=53.08^{\circ}$; i.e., tetrahedral coordination of $\mathrm{Zn}$ lowered the trigonal $\mathrm{Zn}-\mathrm{MnO}_{2}$ to triclinic symmetry.

Although $\mathrm{ZnMn}_{3} \mathrm{O}_{7} \cdot \mathrm{H}_{2} \mathrm{O}$ showed a typical range of $\mathrm{Zn}-\mathrm{O}$ and $\mathrm{Zn}-\mathrm{Mn}$ interatomic distances of $\mathrm{Zn}^{\mathrm{IV}}$, tetrahedral coordination of $\mathrm{Zn}$ significantly changed the birnessite structure in a manner similar to the translation of successive octahedral sheets that Manceau et al. (2002) and Lanson et al. (2002) have observed in $\mathrm{Zn}-\mathrm{MnO}_{2}$. $\mathrm{In}_{\mathrm{ZnMn}} \mathrm{O}_{7} \cdot 3 \mathrm{H}_{2} \mathrm{O}$, two $\mathrm{Zn}$ ions at a vacancy site are aligned with $\mathrm{O}_{3 \mathrm{Mn}}$ of a neighboring sheet (O3 in Table 2) to make a $\mathrm{Zn}-\mathrm{Zn}-\mathrm{O} 3$ angle of $180^{\circ}$. In $\mathrm{ZnMn}_{3} \mathrm{O}_{7} \cdot \mathrm{H}_{2} \mathrm{O}$, the $\mathrm{Zn}$ ions are aligned with a tridentate cavity in the octahedral sheet to make a $\mathrm{Zn}-\mathrm{Zn}-\mathrm{O} 3$ angle of $167^{\circ}$; the apical $\mathrm{O}$ of $\mathrm{H}_{2} \mathrm{O}$ is directed toward the O1-O3 edge in the tridentate cavity instead of toward O3. In the optimized $\mathrm{ZnMn}_{3} \mathrm{O}_{7} \cdot \mathrm{H}_{2} \mathrm{O}$ structure, the separation between neighboring $\mathrm{H}_{2} \mathrm{O}$ molecules was $3.65 \AA$, which is much larger than that in $\mathrm{ZnMn}_{3} \mathrm{O}_{7} \cdot 3 \mathrm{H}_{2} \mathrm{O}(2.76 \AA)$, and the $\mathrm{H}$-bonds between $\mathrm{H}_{2} \mathrm{O}$ and a neighboring octahedral sheet (H...O1 and H...O3) were much shorter (1.71 to $2.10 \AA$ ) than the corresponding H-bonds in $\mathrm{ZnMn}_{3} \mathrm{O}_{7} \cdot 3 \mathrm{H}_{2} \mathrm{O}(2.19$ to $2.49 \AA)$.

This comparison made possible by DFT geometry optimization suggests that H-bonds are stabilized for octahedral $\mathrm{Zn}$ by linking the interlayer $\mathrm{Zn}$ through water molecules, whereas tetrahedral Zn stabilizes its H-bonds with adjacent octahedral sheets by altering the sheet registration to compensate for having no H-bonds between neighboring Zn. Johnson and Post (2006) recently have emphasized the importance of structural water molecules coordinated to interlayer metal cations in determining the stability of birnessite. The present study shows directly that the number of water molecules coordinated to interlayer metal cations in birnessite indeed strongly affects its structural integrity. 


\subsection{Isolated $\mathrm{Zn}^{\mathrm{IV}}$-TCS}

\subsubsection{Geometry-optimized structure}

The geometry-optimized single $\mathrm{Zn}^{\mathrm{IV}}$-TCS yielded structural parameters in excellent agreement with available experimental results (Table 3). The average $\mathrm{Zn}-\mathrm{O}$ and $\mathrm{Zn}-\mathrm{Mn}_{1 \mathrm{st}}$ distances in the optimized $\mathrm{Zn}^{\mathrm{IV}}$-TCS were 1.96 and $3.34 \AA$, respectively, whereas the corresponding experimental distances for $\mathrm{Zn}^{\mathrm{IV}}$-TCS in the $\mathrm{Zn}$-birnessite studied by Marcus et al. (2004) are $1.96 \AA$ and $3.33 \AA$, respectively. In the geometry-optimized complex, the Zn ion was positioned about $0.72 \AA$ above the basal $\mathrm{O}$ plane (Fig. 2a) and the $\mathrm{H}_{2} \mathrm{O}$ molecule hydrating it formed H-bonds of length 1.95 and $1.97 \AA$ with $\mathrm{O}_{3 \mathrm{Mn}}$ of a neighboring sheet. The calculated $d(\mathrm{Mn}-\mathrm{Mn})$ value was 2.83 to $2.94 \AA$, whereas the experimental $d(\mathrm{Mn}-\mathrm{Mn})$ is $2.89 \pm 0.007 \AA$ (Marcus et al., 2004). As in chalcophanite, $d\left(\mathrm{Mn}_{1 \mathrm{st}}-\mathrm{Mn}_{1 \mathrm{st}}\right)$ was somewhat shorter $(2.83-2.87 \AA)$ than $d\left(\mathrm{Mn}_{1 \mathrm{st}}-\mathrm{Mn}_{2 \mathrm{nd}}\right)(2.88-2.94 \AA)$.

\subsubsection{Stability of isolated $\mathrm{Zn}^{I V}-T C S$}

Manceau et al. $(2002,2007)$ have hypothesized that preference for $\mathrm{Zn}^{\mathrm{IV}}$-TCS in birnessite, particularly at a low $\mathrm{Zn} / \mathrm{Mn}$ ratio, occurs because this complex compensates charge deficits on the unsaturated surface $\mathrm{O}\left(\mathrm{O}_{2 \mathrm{Mn}}\right)$ at a Mn vacancy site more effectively than does $\mathrm{Zn}{ }^{\mathrm{VI}}$-TCS. Our DFT optimizations allow a test of this hypothesis using the calculated magnetic moments of $\mathrm{O}_{2 \mathrm{Mn}}$ and the electron overlap population between $\mathrm{Zn}$ and $\mathrm{O}_{2 \mathrm{Mn}}\left(\right.$ Section 2.4). In $\mathrm{ZnMn}_{3} \mathrm{O}_{7} \cdot 3 \mathrm{H}_{2} \mathrm{O}$, the calculated magnetic moment of $\mathrm{O}$ in a water molecule was $0.00 \mu_{B}$ and the magnetic moment of $\mathrm{O}_{3 \mathrm{Mn}}$ was -0.04 to $-0.06 \mu_{B}$, which is indistinguishable from zero. In the vacancy-free $\mathrm{MnO}_{2}$ as 
well as in the $\mathrm{H}_{0.13}\left[\mathrm{Mn}_{0.967} \square_{0.033}\right] \mathrm{O}_{2}$ supercell with two $\mathrm{H}$ replaced by a $\mathrm{Zn}$, the magnetic moment of $\mathrm{O}_{3 \mathrm{Mn}}$ was $-0.04 \mu_{B}$. [A slightly negative spin polarization of $p$ orbitals in nonmagnetic elements like $\mathrm{O}$ typically occurs as a result of $p$ - $d$ hybridization in ferromagnetic transition metal compounds (Kanamori and Terakura, 2001)]. On the other hand, unsaturated $\mathrm{O}_{2 \mathrm{Mn}}$ without bonds with $\mathrm{Zn}$ or $\mathrm{H}$ (Fig. 2b) at a vacancy site took on a significant positive spin polarization, yielding a magnetic moment of $+0.12 \mu_{B}$. Considerable induction of positive spin polarization is typical of the outermost unsaturated surface O on metal oxides (Cline et al., 2000; Gallego et al., 2005). Therefore, our calculated magnetic moments of O indicate the degree of undersaturation of $\mathrm{O}_{2 \mathrm{Mn}}$ in $\mathrm{Zn}$ complexes.

Bond valence concepts predict that $\mathrm{O}_{2 \mathrm{Mn}}$ should be very reactive with cations (Manceau et al., 2002). When $\mathrm{H}$ is bonded to $\mathrm{O}_{2 \mathrm{Mn}}$ (i.e., $\left.\mathrm{Mn}_{2}-\mathrm{O} \rightarrow \mathrm{Mn}_{2}-\mathrm{O}-\mathrm{H}\right)$, our DFT calculations show that the magnetic moment of $\mathrm{O}_{2 \mathrm{Mn}}$ changes from $+0.12 \mu_{B}$ to $-0.04 \mu_{B}$, i.e. it becomes like that of saturated $\mathrm{O}_{3 \mathrm{Mn}}$. Upon adsorption of $\mathrm{Zn}$ (i.e., $\mathrm{Mn}_{2}-\mathrm{O} \rightarrow \mathrm{Mn}_{2}-\mathrm{O}-\mathrm{Zn}$ ) to form $\mathrm{Zn}^{\mathrm{IV}}-\mathrm{TCS}$, the magnetic moment of $\mathrm{O}_{2 \mathrm{Mn}}$ decreases to $+0.04 \mu_{B}$, and in $\mathrm{Zn}{ }^{\mathrm{VI}}$-TCS (Fig. 3) it decreases to +0.08 $\mu_{B}$. (Moreover, in doubly-occupied Zn-TCS complexes, described in Section 3.3, the $\mathrm{O}_{2 \mathrm{Mn}}$ magnetic moment drops to $+0.02 \mu_{B}$ in $\mathrm{Zn}^{\mathrm{IV}}$-TCS and to $+0.04 \mu_{B}$ for $\mathrm{Zn}^{\mathrm{VI}}$-TCS, respectively.) Thus our DFT magnetic moment calculations show that formation of $\mathrm{Zn}^{\mathrm{IV}}-\mathrm{TCS}$ renders $\mathrm{O}_{2 \mathrm{Mn}}$ relatively more saturated than does formation of $\mathrm{Zn}^{\mathrm{VI}}-\mathrm{TCS}$, a result which is consistent with the hypothesis of Manceau et al. $(2002,2007)$ concerning the relative stability of $\mathrm{Zn}^{\mathrm{IV}}$-TCS. The greater degree of electron overlap of $\mathrm{Zn}$ with $\mathrm{O}_{2 \mathrm{Mn}}$ in $\mathrm{Zn}^{\mathrm{IV}}-\mathrm{TCS}(0.36|e|)$ than in $\mathrm{Zn}^{\mathrm{VI}}-\mathrm{TCS}(0.26$ $|e|)$ also supports this hypothesis. 
Substitution of Mn(III) ions in the octahedral sheet also can lead to highly undersaturated basal $\mathrm{O}_{2 \mathrm{Mn}}$ and thus favor formation of $\mathrm{Zn}^{\mathrm{IV}}$-TCS relative to $\mathrm{Zn}^{\mathrm{VI}}$-TCS in birnessites (Manceau et al., 2002). However, our current DFT/GGA method was not able to test this mainly because of the over-delocalization tendency of DFT applied to electrons in mixed valence systems (Franchini, 2007). However, our DFT calculations do demonstrate that the stable existence of $\mathrm{Zn}^{\mathrm{IV}}$-TCS complexes in birnessite does not require the concomitant presence of $\mathrm{Mn}(\mathrm{III})$ ions in the $\mathrm{MnO}_{2}$ sheets. As mentioned in Section 2.4, the magnetic moment of an ion can be used to infer its oxidation number [e.g., for isolated $\mathrm{Mn}(\mathrm{IV})$ it is $3 \mu_{B}$, for isolated $\mathrm{Mn}(\mathrm{III})$ it is $4 \mu_{B}$, and for isolated $\mathrm{Mn}(\mathrm{II})$ it is $5 \mu_{B}$.]. Our calculated magnetic moments of the $\mathrm{Mn}$ ions in the geometryoptimized reference compounds, $\mathrm{ZnMn}(\mathrm{IV})_{3} \mathrm{O}_{7} \cdot 3 \mathrm{H}_{2} \mathrm{O}, \mathrm{LiMn}(\mathrm{III}) \mathrm{O}_{2}$, and $\mathrm{Mn}(\mathrm{II}) \mathrm{O}$, were $3.08 \mu_{B}$, $3.86 \mu_{B}$, and $4.70 \mu_{B}$, respectively. The calculated magnetic moments of $\mathrm{Mn}$ in $\mathrm{Zn}^{\mathrm{IV}}$-TCS were all in the range of 3.00 to $3.08 \mu_{B}$, indicating therefore that all $\mathrm{Mn}$ ions are $\mathrm{Mn}(\mathrm{IV})$, as reported experimentally for $\delta-\mathrm{MnO}_{2}$ (Villalobos et al., 2006), biogenic Mn oxide (Toner et al., 2006), and natural vernadite (Manceau et al., 2007).

The stability of $\mathrm{Zn}^{\mathrm{IV}}$-TCS was examined by comparison of the total electronic energies of isolated $\mathrm{Zn}^{\mathrm{VI}}$-TCS and an isomer $\mathrm{Zn}^{\mathrm{IV}}$-TCS that has H-bonds with two neighboring $\mathrm{H}_{2} \mathrm{O}$ $\left[\mathrm{Zn}^{\mathrm{IV}} \cdot 2 \mathrm{H}_{2} \mathrm{O}\right.$ (Fig. 3a)]. We found the total energy of $\mathrm{Zn}^{\mathrm{IV}}$-TCS to be slightly lower (by 11.6 $\mathrm{kJ} / \mathrm{mol}$ ) than that of $\mathrm{Zn}^{\mathrm{VI}}$-TCS (Fig. 3b). This energy comparison along with the magnetic moment and overlap analyses indicates that $\mathrm{Zn}^{\mathrm{IV}}$-TCS is indeed a stable species in hexagonal birnessite interlayers. We did not attempt calculation of the Gibbs energies of these two species (requiring zero-point energies, thermal energies, entropy contribution) or dynamic simulations with more hydrating $\mathrm{H}_{2} \mathrm{O}$ molecules, both of which might provide more comprehensive 
information on stability. Such a small difference in electronic energies between the two isolated isomers also suggests that $\mathrm{Zn}$ coordination can readily shift from tetrahedral $\mathrm{Zn}^{\mathrm{IV}}$-TCS to octahedral $\mathrm{Zn}^{\mathrm{VI}}$-TCS depending on external influences such as interactions with neighboring $\mathrm{Zn}$ (Section 3.1.2). Thus both $\mathrm{Zn}^{\mathrm{IV}}$-TCS and $\mathrm{Zn}^{\mathrm{VI}}$-TCS should be stable in birnessite.

\subsection{Effects of Zn occupancy type}

The value of $d(\mathrm{Zn}-\mathrm{O})$ did not vary significantly with the number of $\mathrm{Zn}$ species at a Mn vacancy site, but instead only with the $\mathrm{Zn}$ coordination number (Tables 3 and 4). However, the

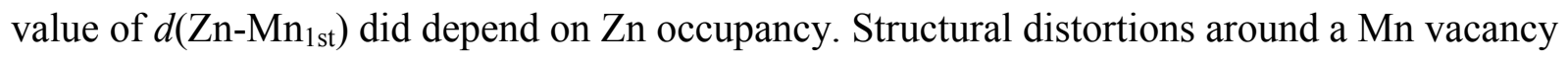
induced by the formation of $\mathrm{Zn}^{\mathrm{VI}}$-TCS $+\mathrm{Zn}^{\mathrm{VI}}$-TCS were exposed clearly by comparison to a constrained geometry-optimized structure of double-occupancy $\mathrm{Zn}-\mathrm{MnO}_{2}$ with fixed $\mathrm{Mn}$ and $\mathrm{O}$ positions (i.e., relaxation of only the two $\mathrm{Zn}$ and $\mathrm{six}_{2} \mathrm{O}$ during optimization, with the other atomic positions fixed at those in geometry-optimized vacancy-free $\mathrm{MnO}_{2}$ ). [The poor prediction of $d\left(\mathrm{Zn}-\mathrm{Mn}_{1 \mathrm{st}}\right), 3.51-3.68 \AA$, in the constrained structure emphasizes the importance of relaxation of the $\mathrm{MnO}_{2}$ coordinates in geometry optimization.] When compared to the constrained structure, the fully-relaxed $\mathrm{Zn}^{\mathrm{VI}}-\mathrm{TCS}+\mathrm{Zn}^{\mathrm{VI}}$-TCS structure revealed that $\mathrm{Mn}_{1 \mathrm{st}}$ move toward the vacancy by $0.08-0.11 \AA$, whereas $\mathrm{O}_{2 \mathrm{Mn}}$ move away from the vacancy by $0.16-0.21$ $\AA$ (Fig. 4a). In order to interpret their EXAFS results, Manceau et al. (2002) postulated shifts of the $\mathrm{O}_{2 \mathrm{Mn}}$ positions outward from a vacancy by $0.15 \AA$ relative to an undistorted birnessite structure based on XRD, and Villalobos et al. (2005) similarly postulated a $0.09 \AA$ shift of $\mathrm{O}_{2 \mathrm{Mn}}$ positions outward from a vacancy in $\mathrm{Pb}-\mathrm{MnO}_{2}$. 
These displacements of $\mathrm{Mn}_{1 \mathrm{st}}$ and $\mathrm{O}_{2 \mathrm{Mn}}$ can be understood readily in terms of cation repulsion and the screening of the cationic charge by $\mathrm{O}$. Absence of one Mn cation out of three lessens the local repulsive energy, and it allows the surrounding Mn ions to contract about the vacancy, shortening the $d\left(\mathrm{Mn}_{1 s t}-\mathrm{Mn}_{1 \mathrm{st}}\right)$ from $2.90 \AA$ to $2.84 \AA$ (Fig. $\left.4 \mathrm{~b}\right)$. At the same time, compensating $\mathrm{O}_{2 \mathrm{Mn}}$ displacement outward from the vacancy occurs to screen the cationic charge of the $\mathrm{Mn}_{1 \mathrm{st}}$ such that the angle $\mathrm{Mn}_{1 \mathrm{st}}-\mathrm{O}_{2 \mathrm{Mn}}-\mathrm{Mn}_{1 \mathrm{st}}$ enlarges from $97.6^{\circ}$ to $99.4-99.6^{\circ}$, the sharededge length of $\mathrm{Mn}_{1 \text { st }}$ octahedra $\left[d\left(\mathrm{O}-\mathrm{O}_{\mathrm{Mn} 1 \mathrm{st}}\right)\right]$ decreases from $2.54 \AA$ to $2.52 \AA$, and that of vacant octahedron $\left[d\left(\mathrm{O}-\mathrm{O}_{\text {vac }}\right)\right]$ increases from $2.54 \AA$ to $2.72 \AA$. Octahedral distortion includes significant variation in the distance between $\mathrm{Mn}$ and $\mathrm{O}[d(\mathrm{Mn}-\mathrm{O})]$, from $1.93 \AA$ to $1.86-1.97 \AA$.

Octahedrally-coordinated $\mathrm{Zn}$ has a larger radius than tetrahedrally-coordinated $\mathrm{Zn}$, so octahedral $\mathrm{Zn}^{\mathrm{VI}}-\mathrm{TCS}+\mathrm{Zn}^{\mathrm{VI}}$-TCS has a much larger separation of the two $\mathrm{Zn}$ through the vacancy $[d(\mathrm{Zn}-\square-\mathrm{Zn})]$ than does tetrahedral $\mathrm{Zn}^{\mathrm{IV}}$-TCS $+\mathrm{Zn}^{\mathrm{IV}}$-TCS (4.17 $\AA$ vs. $3.34 \AA$, Fig. 5). The $\mathrm{Zn}$ cations in tetrahedral coordination thus exert more repulsion on nearby $\mathrm{Mn}$, and hence the $\mathrm{Mn}_{1 \mathrm{st}}$ do not move inward as much as they do in the octahedral system: smaller movement by $0.04-0.05 \AA$ in the former case, yielding $d\left(\mathrm{Mn}_{1 \mathrm{st}}-\mathrm{Mn}_{1 \mathrm{st}}\right)=2.88 \AA$ (Fig. 4c) than in the latter case, yielding $\left[d\left(\mathrm{Mn}_{1 \mathrm{st}}-\mathrm{Mn}_{1 \mathrm{st}}\right)=2.84 \AA\right.$ (Fig. $\left.\left.4 \mathrm{~b}\right)\right]$. The $\mathrm{O}_{2 \mathrm{Mn}}$ move outward by $0.15-0.24 \AA$, which is slightly greater than in the octahedral system, with smaller $d\left(\mathrm{O}-\mathrm{O}_{\mathrm{Mn} 1 \mathrm{st}}\right)(2.50 \AA)$ and larger $d(\mathrm{O}-$ $\left.\mathrm{O}_{\text {vac }}\right)(2.76 \AA)$ (Fig. 4c). The value of $d(\mathrm{Mn}-\mathrm{O})$ was $1.89-1.95 \AA$.

Homogeneous $\mathrm{Zn}$ occupancy yields a homogeneous $d\left(\mathrm{Mn}_{1 \mathrm{st}}-\mathrm{Mn}_{1 \mathrm{st}}\right)$ as a result of equivalent repulsions, mainly between Zn-TCS at the vacancy site (see the charge density of ZnTCS in Fig. 5a, b). The mixed-occupancy structure $\mathrm{Zn}^{\mathrm{IV}}-\mathrm{TCS}+\mathrm{Zn}^{\mathrm{VI}}-\mathrm{TCS}$, however, shows two different $d\left(\mathrm{Mn}_{1 \mathrm{st}}-\mathrm{Mn}_{1 \mathrm{st}}\right)$ values, $2.88 \AA$ and $2.85 \AA$ (Table 4), implying unequal electrostatic 
interactions for the two types of $\mathrm{Zn}$ complex (Fig. 5c). The mixed-occupancy structure exhibits $d(\mathrm{Zn}-\square-\mathrm{Zn})=3.72 \AA$, which lies between the corresponding values for the homogeneousoccupancy structures ( $3.34 \AA$ and $4.17 \AA$ ). In the mixed occupancy structure, the presence of octahedral $\mathrm{Zn}$ results in less repulsion of tetrahedral $\mathrm{Zn}$ than in $\mathrm{Zn}^{\mathrm{IV}}-\mathrm{TCS}+\mathrm{Zn}^{\mathrm{IV}}-\mathrm{TCS}$, thus

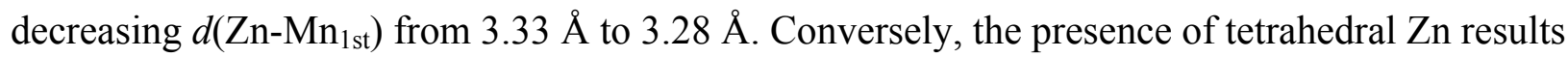
in more repulsion of the octahedral $\mathrm{Zn}$ than in $\mathrm{Zn}^{\mathrm{VI}}-\mathrm{TCS}+\mathrm{Zn}^{\mathrm{VI}}-\mathrm{TCS}$, thereby increasing $d(\mathrm{Zn}$ $\left.\mathrm{Mn}_{1 \mathrm{st}}\right)$ from $3.52 \AA$ to $3.56 \AA$.

\subsection{1. $Z n^{I V}-T C S+Z n^{I V}-T C S$}

Our calculated $d\left(\mathrm{Zn}-\mathrm{Mn}_{1 \mathrm{st}}\right)$ for $\mathrm{Zn}^{\mathrm{IV}}-\mathrm{TCS}+\mathrm{Zn}^{\mathrm{IV}}-\mathrm{TC}(3.33 \AA)$ is consistent with experimental values for tetrahedrally-coordinated Zn reported by Marcus et al. (2004) and Isaure et al.(2005) for natural birnessites ( $3.33 \pm 0.02 \AA)$ and by Toner et al. (2006) for a biogenic $\mathrm{MnO}_{2}(3.36 \pm 0.03 \AA)$ and $\delta-\mathrm{MnO}_{2}(3.39 \pm 0.02 \AA)$. The angle between the $\mathrm{Zn}-\mathrm{Mn}_{1 \text { st }}$ pair and the octahedral sheet normal ( $\beta$ angle) was $59.1-60.2^{\circ}$ and $d(\mathrm{Zn}-\square-\mathrm{Zn})$ was $3.34 \AA$ according to our DFT optimization (Fig. 5a). To interpret their polarized EXAFS data on a synthetic Zn-birnessite, Manceau et al. (2002) developed a structural model of $\mathrm{Zn}^{\mathrm{IV}}-\mathrm{TCS}+\mathrm{Zn}^{\mathrm{IV}}-\mathrm{TCS}$ based on chalcophanite, wherein the $\beta$ angle and $d(\mathrm{Zn}-\square-\mathrm{Zn})$ were significantly different $\left(56.4^{\circ}\right.$ and 3.54 $\AA$, respectively) from our results, even though they fixed $d\left(\mathrm{Zn}-\mathrm{Mn}_{1 \mathrm{st}}\right)$ at $3.35 \AA$. In the fullyrelaxed $\mathrm{ZnMn}_{3} \mathrm{O}_{7} \cdot \mathrm{H}_{2} \mathrm{O}$ optimization (Section 3.1.2), the $\beta$ angle and $d(\mathrm{Zn}-\square-\mathrm{Zn}$ ) were $58.6-$ $59.3^{\circ}$ and $3.50 \AA$, respectively, which are similar to the values of Manceau et al. (2002). These comparisons suggest that a tetrahedral $\mathrm{Zn}$ model developed with fixed chalcophanite coordinates may not accurately capture the detailed structure of $\mathrm{Zn}^{\mathrm{IV}}$-TCS found in $\mathrm{Zn}$-birnessite. 


\subsection{2. $Z n^{V I}-T C S+Z n^{V I}-T C S$}

In the geometry-optimized $\mathrm{Zn}^{\mathrm{VI}}-\mathrm{TCS}+\mathrm{Zn}^{\mathrm{VI}}$-TCS structure, the value of $d\left(\mathrm{Zn}-\mathrm{Mn}_{1 \mathrm{st}}\right)$ was $3.52 \AA$ with $\beta$ angle $53.5-54.1^{\circ}, d\left(\mathrm{Mn}_{1 \mathrm{st}}-\mathrm{Mn}_{1 \mathrm{st}}\right)$ was $2.84 \AA$, and $d(\mathrm{Zn}-\square-\mathrm{Zn})$ was $4.17 \AA$ (Fig.

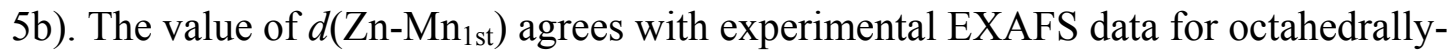
coordinated $\mathrm{Zn}$ in biogenic $\mathrm{MnO}_{2}(3.51 \pm 0.02 \AA), \delta-\mathrm{MnO}_{2}(3.53 \pm 0.02 \AA)$, reported by Toner et al. (2006), and in chalcophanite (3.52 $\AA$ ), reported by Manceau et al. (2002). The DFT $\beta$ angle and $d(\mathrm{Zn}-\square-\mathrm{Zn})$ value are both consistent with experimental XRD structural data for chalcophanite, whose $\beta$ angle is $53.6^{\circ}$ and $d(\mathrm{Zn}-\square-\mathrm{Zn}$ ) value is $4.16 \AA$ (Post and Appleman, 1988; Manceau et al., 2002).

\subsection{3. $Z n^{I V}-T C S+Z n^{V I}-T C S$}

In the mixed-occupancy structure (Fig. $5 \mathrm{c}), d\left(\mathrm{Zn}-\mathrm{Mn}_{1 \mathrm{st}}\right)$ for tetrahedral $\mathrm{Zn}$ was $3.28 \AA$ ( $\beta$ angle $\left.=60.5^{\circ}\right)$, which is smaller than that in $\mathrm{Zn}^{\mathrm{IV}}-\mathrm{TCS}+\mathrm{Zn}^{\mathrm{IV}}-\mathrm{TCS}(3.33 \AA)$, while $d\left(\mathrm{Zn}^{\left.-\mathrm{Mn}_{1 \mathrm{st}}\right)}\right.$ for octahedral $\mathrm{Zn}$ was $3.56 \AA\left(\beta\right.$ angle $\left.=53.2-53.7^{\circ}\right)$, which is larger than that in $\mathrm{Zn}{ }^{\mathrm{VI}}$ - TCS + $\mathrm{Zn}^{\mathrm{VI}}$-TCS (3.52 $\AA$ ). Although the DFT Zn-O distances were consistent with experimental data, these $d\left(\mathrm{Zn}-\mathrm{Mn}_{1 \mathrm{st}}\right)$ values do not match available experimental distances for tetrahedral (3.33 $3.39 \AA)$ and octahedral $(3.50-3.53 \AA) \mathrm{Zn}$. Therefore, the mixed-occupancy structure may not occur in nature. On the other hand, Manceau et al. (2002) reported single-shell EXAFS analyses for synthetic $\mathrm{Zn}$-birnessites containing both tetrahedral and octahedral $\mathrm{Zn}$ in which $d\left(\mathrm{Zn}^{\left.-\mathrm{Mn}_{1 \mathrm{st}}\right)}\right.$ was 3.45-3.48 $\AA$. This range, which applies to an approximately 1:3 mixture of the two $\mathrm{Zn}$ 
coordination environments, is close to our average $d\left(\mathrm{Zn}-\mathrm{Mn}_{1 \mathrm{st}}\right)$ for both $\mathrm{Zn}^{\mathrm{IV}}-\mathrm{TCS}+\mathrm{Zn}^{\mathrm{VI}}-\mathrm{TCS}$ $(3.42 \AA)$ and a $1: 1$ mixture of $\mathrm{Zn}^{\mathrm{IV}}-\mathrm{TCS}+\mathrm{Zn}^{\mathrm{IV}}$-TCS plus $\mathrm{Zn}^{\mathrm{VI}}-\mathrm{TCS}+\mathrm{Zn}^{\mathrm{VI}}-\mathrm{TCS}(3.43 \AA)$.

\section{CONCLUSIONS}

Our DFT study provides insight into the occurrence of $\mathrm{Zn}^{\mathrm{IV}}$ and $\mathrm{Zn}{ }^{\mathrm{VI}}$ surface complexes at $\mathrm{Mn}$ vacancies in hexagonal birnessite, demonstrating that $\mathrm{Zn}^{\mathrm{IV}}$ forms stronger chemical bonds with $\mathrm{O}$ of a $\mathrm{Mn}(\mathrm{IV})$ vacancy site than $\mathrm{Zn}^{\mathrm{VI}}$ does. This is consistent with experimental observations of the predominance of $\mathrm{Zn}^{\mathrm{IV}}$-TCS at low loading of sorbed $\mathrm{Zn}$ in birnessite. On the other hand, the calculated total electronic energy of $\mathrm{Zn}^{\mathrm{IV}}$-TCS $\mathrm{MnO}_{2}$, which is lower than but close to that of $\mathrm{Zn}^{\mathrm{VI}}-\mathrm{TCS} \mathrm{MnO}_{2}\left(11.6 \mathrm{~kJ} / \mathrm{mol}\right.$ difference), indicates that $\mathrm{Zn}^{\mathrm{IV}}$-TCS and $\mathrm{Zn}^{\mathrm{VI}}-\mathrm{TCS}$ surface complexes both can occur in birnessite interlayers, as observed experimentally, despite the difference in bond strength of $\mathrm{Zn}$. Comparison between $\mathrm{ZnMn}_{3} \mathrm{O}_{7} \cdot 3 \mathrm{H}_{2} \mathrm{O}$ and $\mathrm{ZnMn}_{3} \mathrm{O}_{7} \cdot \mathrm{H}_{2} \mathrm{O}$, which have a high $\mathrm{Zn} / \mathrm{Mn}$ ratio, suggests that occurrence of $\mathrm{Zn}^{\mathrm{VI}}$-TCS along with $\mathrm{Zn}^{\mathrm{IV}}$-TCS in hexagonal birnessite may be more related to Zn-birnessite stability mediated by interactions of Zn ions (e.g., through H-bonding) with neighboring $\mathrm{Zn}$ ions or with adjacent $\mathrm{Mn}$ octahedral sheets than to the existence of $\mathrm{Mn}$ (III) substitution and $\mathrm{Zn}$ bond-strength difference. A direct calculation of the relative stability would require the inclusion not only of quantum zero-point energy but also of additional thermally disordered water of hydration and the computation of accurate free energies, which lies beyond the scope of this paper.

Our geometry-optimization based on DFT has also enabled us to explore structural relaxation around $\mathrm{Mn}$ vacancies, a difficult task for current experimental techniques. The detailed structures of isolated $\mathrm{Zn}$-TCS species and Mn vacancies in hexagonal $\mathrm{Mn}(\mathrm{IV}) \mathrm{O}_{2}$ 
obtained by our DFT study can serve as fully-characterized end-member species of ZnTCS to facilitate the interpretation of spectroscopic data on Zn sorbed in birnessite and thus help to achieve accurate modeling of the fate of $\mathrm{Zn}$ in terrestrial and aquatic environments.

\section{ACKNOWLEDGMENTS}

This research reported in this paper was supported by the Director, Office of Energy Research, Office of Basic Energy Sciences, of the U.S. Department of Energy under Contract No. DE-AC02-05CH11231. Our computations used resources of the National Energy Research Scientific Computing Center, which is supported by the Office of Science of the U.S. Department of Energy under contract No. DE-AC02-05CH11231. We also acknowledge the use of the SCARF computing facilities at STFC Rutherford Appleton Laboratory.

\section{REFERENCES}

Balachandran D., Morgan D., Ceder G., and van de Walle A. (2003) First-principles study of the structure of stoichiometric and Mn-deficient MnO2. J. Solid State Chem. 173, 462-475.

Clark S. J., Segall M. D., Pickard, C. J., Hasnip, P. J., Probert, M. J., Refson, K., and Payne, M.C. (2005) First principles methods using CASTEP. Z. Kristallogr. 220, 567-570.

Cline J. A., Rigos A. A., and Arias T. A. (2000) Ab initio study of magnetic structure and chemical reactivity of $\mathrm{Cr}_{2} \mathrm{O} 3$ and its (0001) surface. J. Phys. Chem. B 104, 61956201.

Cohen A. J. and Gordon R. G. (1976) Modified electron-gas study of stability, elastic properties, and high-pressure behavior of $\mathrm{MgO}$ and $\mathrm{CaO}$ crystals. Phys. Rev. B 14, 4593-4605.

Cramer C. J. (2003) Essentials of Computational Chemistry. John Wiley \& Sons Ltd, Chichester.

Dudev T. and Lim C. (2000) Tetrahedral vs octahedral zinc complexes with ligands of biological interest: A DFT/CDM study. J. Am. Chem. Soc. 122, 11146-11153. 
Franchini C., Podloucky R., Paier J., Marsman M., and Kresse G. (2007) Ground-state properties of multivalent manganese oxides: Density functional and hybrid density functional calculations. Phys. Rev. B 75, 195128-11.

Gaillot A. C., Flot D., Drits V. A., Manceau A., Burghammer M., and Lanson B. (2003) Structure of synthetic K-rich birnessite obtained by high-temperature decomposition of $\mathrm{KMnO}_{4}$. I. Two-layer polytype from $800^{\circ} \mathrm{C}$ experiment. Chem. Mater. 15, 4666-4678.

Gallego S., Beltrán J. I., Cerdá J., and Muñoz M. C. (2005) Magnetism and half-metallicity at the O surfaces of ceramic oxides. J. Phys. Condens. Matter 17, L451-L457.

Isaure M. P., Manceau A., Geoffroy N., Laboudigue A., Tamura N., and Marcus M. A. (2005) Zinc mobility and speciation in soil covered by contaminated dredged sediment using micrometer-scale and bulk-averaging X-ray fluorescence, absorption and diffraction techniques. Geochim. Cosmochim. Acta 69, 1173-1198.

Johnson E. A. and Post J. E. (2006) Water in the interlayer region of birnessite: Importance in cation exchange and structural stability. Am. Mineral. 91, 609-618.

Kanamori J. and Terakura I. (2001) A general mechanism underlying ferromagnetism in transition metal compounds. J. Phys. Soc. Jpn. 70, 1433-1434.

Kim S. H., Kim S. J., and Oh S. M. (1999) Preparation of layered $\mathrm{MnO}_{2}$ via thermal decomposition of $\mathrm{KMnO}_{4}$ and its electrochemical characterizations. Chem. Mater. 11, 557-563.

Koch W. and Holthausen M. C. (2002) A Chemist's Guide to Density Functional Theory. Wiley$\mathrm{VCH}$, New York.

Kohanoff J. (2006) Electronic Structure Calculations for Solids and Molecules: Theory and Computational Methods. University Cambridge Press, Cambridge.

Kohn W. and Sham L. J. (1965) Self-consistent equations including exchange and correlation effects. Phys. Rev. 140, A1133-A1138.

Kresse G. and Furthmüller J. (1996) Efficient iterative schemes for ab initio total-energy calculations using a plane-wave basis set. Phys. Rev. B 54, 11169-11186.

Lanson B., Drits V. A., Gaillot A. C., Silvester E., Plancon A., and Manceau A. (2002) Structure of heavy-metal sorbed birnessite: Part 1. Results from X-ray diffraction. Am. Mineral. 87, 1631-1645. 
Lanson B., Marcus M. A., Fakra S., Panfili F., Geoffroy N., and Manceau A. (2008) Formation of Zn-Ca phyllomanganate nanoparticles in grass roots. Geochim. Cosmochim. Acta, $\mathbf{7 2}$, 2478-2490.

Manceau A., Lanson B., and Drits V. A. (2002) Structure of heavy metal sorbed birnessite. Part III: Results from powder and polarized extended X-ray absorption fine structure spectroscopy. Geochim. Cosmochim. Acta 66, 2639-2663.

Manceau A., Lanson M., and Geoffroy N. (2007) Natural speciation of Ni, Zn, Ba, and As in ferromanganese coatings on quartz using X-ray fluorescence, absorption, and diffraction. Geochim. Cosmochim. Acta 71, 95-128.

Marcus M. A., Manceau A., and Kersten M. (2004) Mn, Fe, Zn and As speciation in a fastgrowing ferromanganese marine nodule. Geochim. Cosmochim. Acta 68, 3125-3136.

Martin R. M. (2004) Electronic Structure: Basic Theory and Practical Methods. Cambridge University Press, Cambridge.

Mattsson A. E., Schultz P. A., Desjarlais M. P., Mattsson T. R., and Leung K. (2005) Designing meaningful density functional theory calculations in materials science-a primer. Model. Simul. Mater. Sci. Eng. 13, R1-R31.

Milman V., Winkler B., White J. A., Pickard C. J., Payne M. C., Akhmatskaya, E. V., and Nobes, R. H. (2000) Electronic structure, properties, and phase stability of inorganic crystals: A pseudopotential plane-wave study. Int. J. Quantum Chem. 77, 895-910.

Mishra S. K. and Ceder G. (1999) Structural stability of lithium manganese oxides. Phys. Rev. B 59, 6120-6130.

Miyata N., Tani Y., Sakata M., and Iwahori K. (2007) Microbial manganese oxide formation and interaction with toxic metal ions. J. Biosci. Bioeng. 104, 1-8.

Monkhorst H. J. and Pack J. D. (1976) Special points for Brillouin-zone integrations. Phys. Rev. $B$ 13, 5188-5192.

Moessner R. and Ramirez A. R. (2006) Geometrical frustration. Physics Today 59, 24-29.

Mulliken R. S. (1955) Electronic population analysis on LCAO-MO molecular wave functions. I. J. Chem. Phys. 23, 1833-1840.

Pask J. E., Singh D. J., Mazin I. I., Hellberg C. S., and Kortus J. (2001) Structural, electronic, and magnetic properties of MnO. Phys. Rev. B 64, 024403. 
Payne M. C., Teter M. P., Allan,D. C., Arias T. A., and Joannopoulos J. D. (1992) Iterative minimization techniques for ab initio total-energy calculations: molecular-dynamics and conjugate gradients. Rev. Mod. Phys. 64, 1045-1097.

Perdew J. P., Burke K., and Ernzerhof M. (1996) Generalized gradient approximation made simple. Phys. Rev. Lett. 77, 3865-3868.

Pfrommer B. G., Cote M., Louie S. G., and Cohen M. L. (1997) Relaxation of crystals with the quasi-Newton method. J. Comput. Phys. 131, 233-240.

Post J. E. and Appleman D. E. (1988) Chalcophanite, $\mathrm{ZnMn}_{3} \mathrm{O}_{7} \cdot 3 \mathrm{H}_{2} \mathrm{O}$ - New crystal-structure determinations. Am. Mineral. 73, 1401-1404.

Probert M. I. J. (2003) Improved algorithm for geometry optimisation using damped molecular dynamics. J. Comput. Phys. 191, 130-146.

Probert M. I. J. and Payne M. C. (2003) Improving the convergence of defect calculations in supercells: An ab initio study of the neutral silicon vacancy. Phys. Rev. B 67, 075204.

Segall M. D., Lindan P. J. D., Probert M. J., Pickard C. J., Hasnip,P. J., Clark S. J., and Payne M. C. (2002) First-principles simulation: ideas, illustrations and the CASTEP code. J. Phys. Condens. Matter 14, 2717-2744.

Segall, M. D., Shah, R., Pickard, C. J., and Payne, M. C. (1996) Population analysis of planewave electronic structure calculations of bulk materials. Phys. Rev. B 54, 16317-16320.

Singh, D. J. (1997) Magnetic and electronic properties of $\mathrm{LiMnO}_{2}$. Phys. Rev. B 55, 309-312.

Tebo B. M., Bargar J. R., Clement B. G., Dick G. J., Murray K. J., Parker D., Verity R., and Webb S. M. (2004) Biogenic manganese oxides: Properties and mechanisms of formation. Annu. Rev. Earth Planet. Sc. 32, 287-328.

Toner B., Manceau A., Webb S. M., and Sposito G. (2006) Zinc sorption to biogenic hexagonalbirnessite particles within a hydrated bacterial biofilm. Geochim. Cosmochim. Acta 70, $27-43$.

Tonkin J. W., Balistrieri L. S., and Murray J. W. (2004) Modeling sorption of divalent metal cations on hydrous manganese oxide using the diffuse double layer model. Appl. Geochem. 19, 29-53.

Vanderbilt D. (1990) Soft self-consistent pseudopotentials in a generalized eigenvalue formalism. Phys. Rev. B 41, 7892-7895. 
Villalobos M., Bargar J., and Sposito G. (2005) Mechanisms of Pb(II) sorption on a biogenic manganese oxide. Environ. Sci. Technol. 39, 569-576.

Villalobos M., Lanson B., Manceau A., Toner B., and Sposito G. (2006) Structural model for the biogenic Mn oxide produced by Pseudomonas putida. Am. Mineral. 91, 489-502.

Zhao J. L., Zhang W. Q., Li X. M., Feng J. W., and Shi X. (2006) Convergence of the formation energies of intrinsic point defects in wurtzite $\mathrm{ZnO}$ : first-principles study by projector augmented wave method. J. Phys. Condens. Matter 18, 1495-1508. 


\section{Figure Captions}

Fig. 1. Geometry-optimized structures of $\mathrm{Zn}$ complexes and $\mathrm{Mn}$ octahedra in $\mathrm{ZnMn}_{3} \mathrm{O}_{7} \cdot 3 \mathrm{H}_{2} \mathrm{O}$ (chalcophanite), viewed perpendicularly to (a) the $c$-axis and (b) the $a b$ plane (Red: O; White: H; Teal: Zn; Purple octahedron: Mn(IV) octahedron). Interatomic distances, H-bond distances (dotted lines), and sheet thickness are given in $\AA$. $\mathrm{H}_{2} \mathrm{O}$ molecules are omitted for visual clarity in (b). Double-headed arrow in (b) indicates the distance between nearest-neighbor $\mathrm{Mn}\left(\mathrm{Mn}_{1 \mathrm{st}}\right)$ and $\mathrm{Zn}$. Gray octahedra represent $\mathrm{Mn}_{1 \text { st }}$ ones from $\mathrm{Zn}$. The labels $\mathrm{O} 1$ and $\mathrm{O} 3$ identify $\mathrm{O}$ bonded to three $\mathrm{Mn}\left(\mathrm{O}_{3 \mathrm{Mn}}\right)$, whereas $\mathrm{O} 2$ identifies $\mathrm{O}$ bonded to two $\mathrm{Mn}$ and one $\mathrm{Zn}\left(\mathrm{O}_{2 \mathrm{Mn}}\right)$ (See Table 2 for their coordinates).

Fig. 2. Geometry-optimized isolated $\mathrm{Zn}^{\mathrm{IV}}$-TCS in $4 \times 4 \times 1$ supercell $\mathrm{Mn}(\mathrm{IV}) \mathrm{O}_{2}(11.587 \AA$ x 11.587 $\AA \mathrm{x} 14.001 \AA$ ), viewed perpendicularly to (a) the $c$-axis and (b) the $a b$ plane. Labeling and color scheme is the same as in Fig. 1. Double-headed arrows in (b) indicate interatomic distances in $\AA$. $\mathrm{Mn}_{2 n d}: \mathrm{Mn}$ second-nearest to $\mathrm{Zn}$; $\mathrm{O}_{2 \mathrm{Mnx}}$ : O bonded to two Mn but no $\mathrm{H}$ or $\mathrm{Zn}$.

Fig. 3. Geometry-optimized (a) isolated $\mathrm{Zn}^{\mathrm{IV}}$-TCS that has $\mathrm{H}$-bonds with two $\mathrm{H}_{2} \mathrm{O}$ and (b) isolated $\mathrm{Zn}{ }^{\mathrm{VI}}$-TCS. Labeling and color scheme is the same as in Fig. 1. Values in parentheses are electron overlap population in $\mathrm{Zn}-\mathrm{O}_{2 \mathrm{Mn}}$ bond.

Fig. 4. View of a vacancy in the $a b$ plane ( $\mathrm{Zn}$ and $\mathrm{H}_{2} \mathrm{O}$ molecules omitted for visual clarity) of (a) constrained $\mathrm{Zn}^{\mathrm{VI}}-\mathrm{TCS}+\mathrm{Zn}^{\mathrm{VI}}$-TCS with atomic coordinates for $\mathrm{MnO}_{2}$ fixed (see text), (b) $\mathrm{Zn}^{\mathrm{VI}}-\mathrm{TCS}+\mathrm{Zn}^{\mathrm{VI}}-\mathrm{TCS}$ with the coordinates for $\mathrm{MnO}_{2}$ relaxed, and (c) $\mathrm{Zn}^{\mathrm{IV}}-\mathrm{TCS}+\mathrm{Zn}^{\mathrm{IV}}-\mathrm{TCS}$ 
with the coordinates for $\mathrm{MnO}_{2}$ relaxed. Labeling and color scheme is the same as in Fig. 1. Single-headed arrows in (a) represent the directions of $\mathrm{Mn}$ and $\mathrm{O}$ displacements upon structural relaxation. Double-headed arrows denote $d\left(\mathrm{Mn}_{1 \mathrm{st}}-\mathrm{Mn}_{1 \mathrm{st}}\right), d\left(\mathrm{O}-\mathrm{O}_{\mathrm{Mn} 1 \mathrm{st}}\right)$, and $d\left(\mathrm{O}-\mathrm{O}_{\text {vac }}\right)$ in $\AA$. In the (a) constrained $\mathrm{Zn}^{\mathrm{VI}}-\mathrm{TCS}+\mathrm{Zn}^{\mathrm{VI}}-\mathrm{TCS}, d\left(\mathrm{Mn}_{1 \mathrm{st}}-\mathrm{Mn}_{1 \mathrm{st}}\right)=2.90 \AA$ and $d\left(\mathrm{O}-\mathrm{O}_{\mathrm{Mn} 1 \mathrm{st}}\right)$ and $d\left(\mathrm{O}-\mathrm{O}_{\text {vac }}\right)$ both equal $2.54 \AA$.

Fig. 5. Charge densities of ions relative to the corresponding neutral atoms, section taken parallel to the $a c$ plane in (a) $\mathrm{Zn}^{\mathrm{IV}}-\mathrm{TCS}+\mathrm{Zn}^{\mathrm{IV}}-\mathrm{TCS}$, (b) $\mathrm{Zn}^{\mathrm{VI}}-\mathrm{TCS}+\mathrm{Zn}^{\mathrm{VI}}-\mathrm{TCS}$, and (c) mixed $\mathrm{Zn}^{\mathrm{IV}}-\mathrm{TCS}$ $+\mathrm{Zn}^{\mathrm{VI}}$-TCS. (Red: O; White: H; Teal: Zn; Purple: Mn). Blue areas represent electron-depleted regions and red areas represent electron-rich regions. Solid arrows indicate $d(\mathrm{Zn}-\square-\mathrm{Zn})$, while dotted arrows indicate $d\left(\mathrm{Zn}-\mathrm{Mn}_{1 \mathrm{st}}\right)$, both in $\AA$. 
Fig. 1
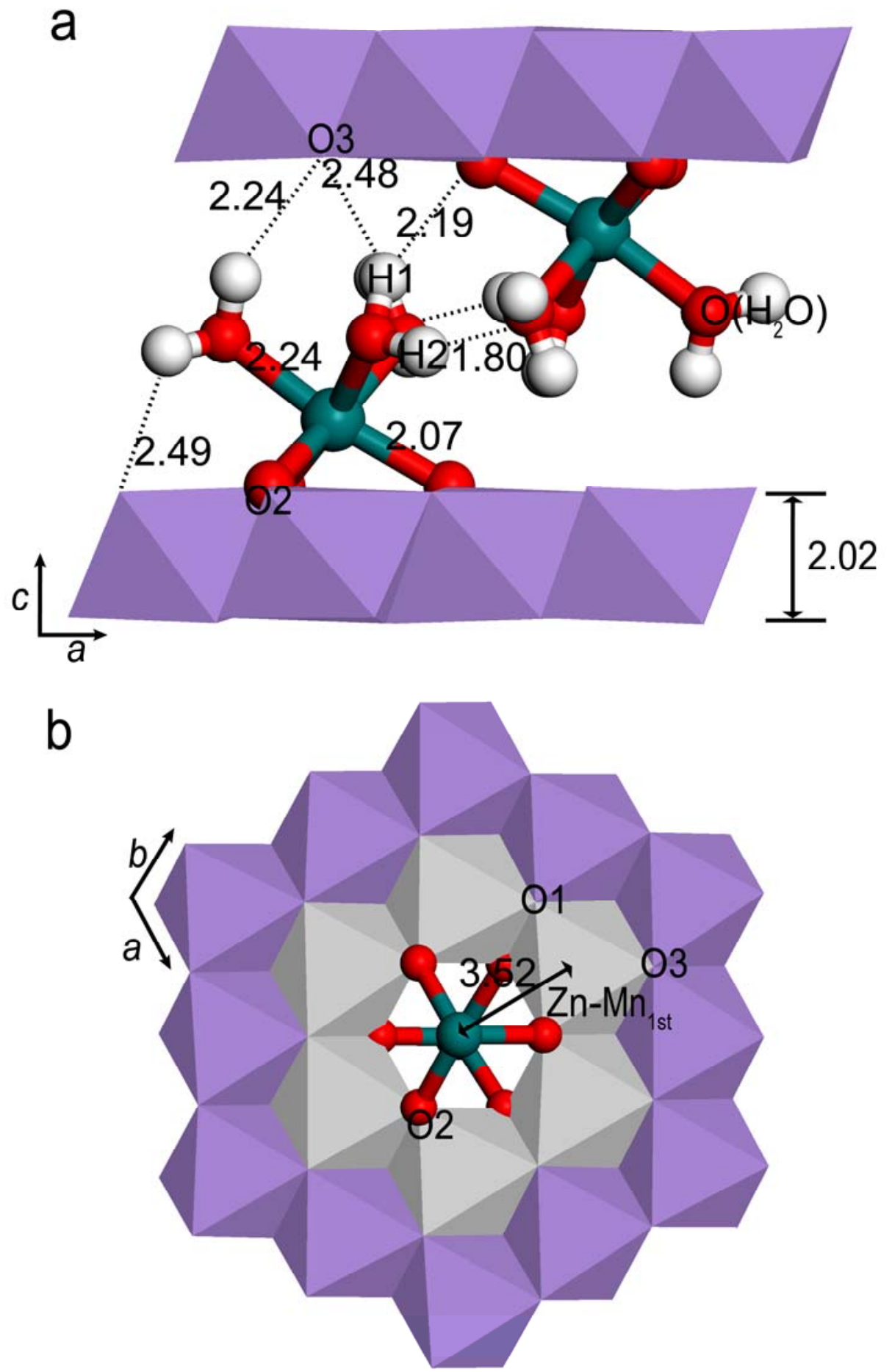
Fig. 2
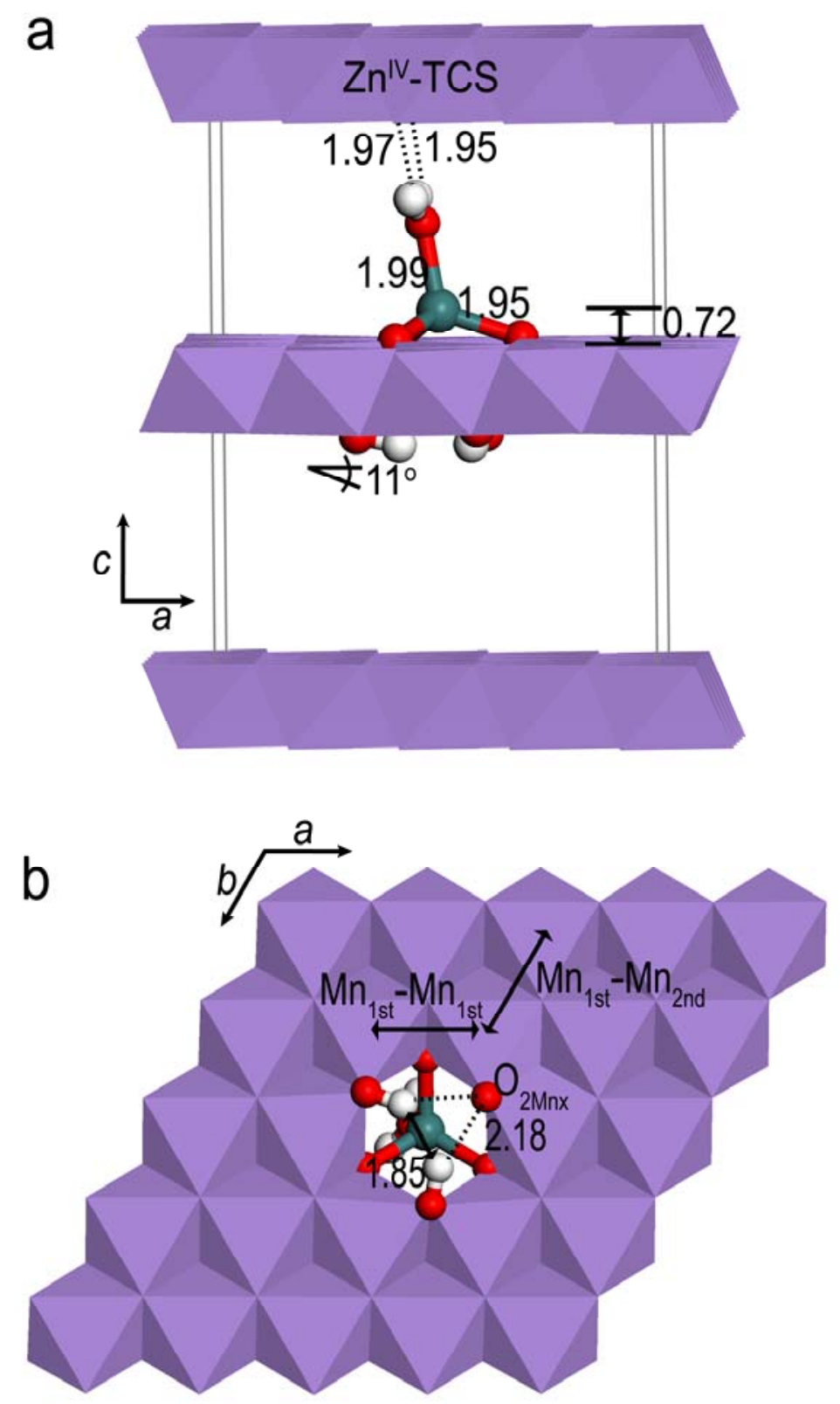
Fig. 3

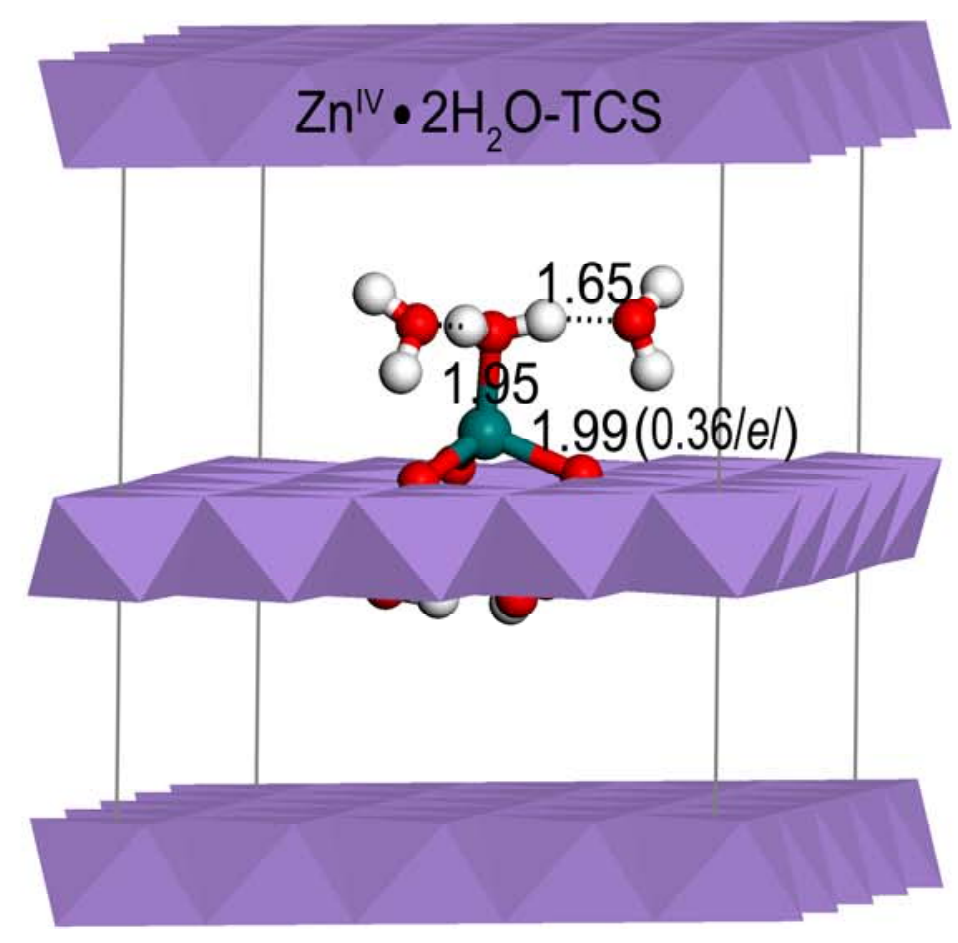

a

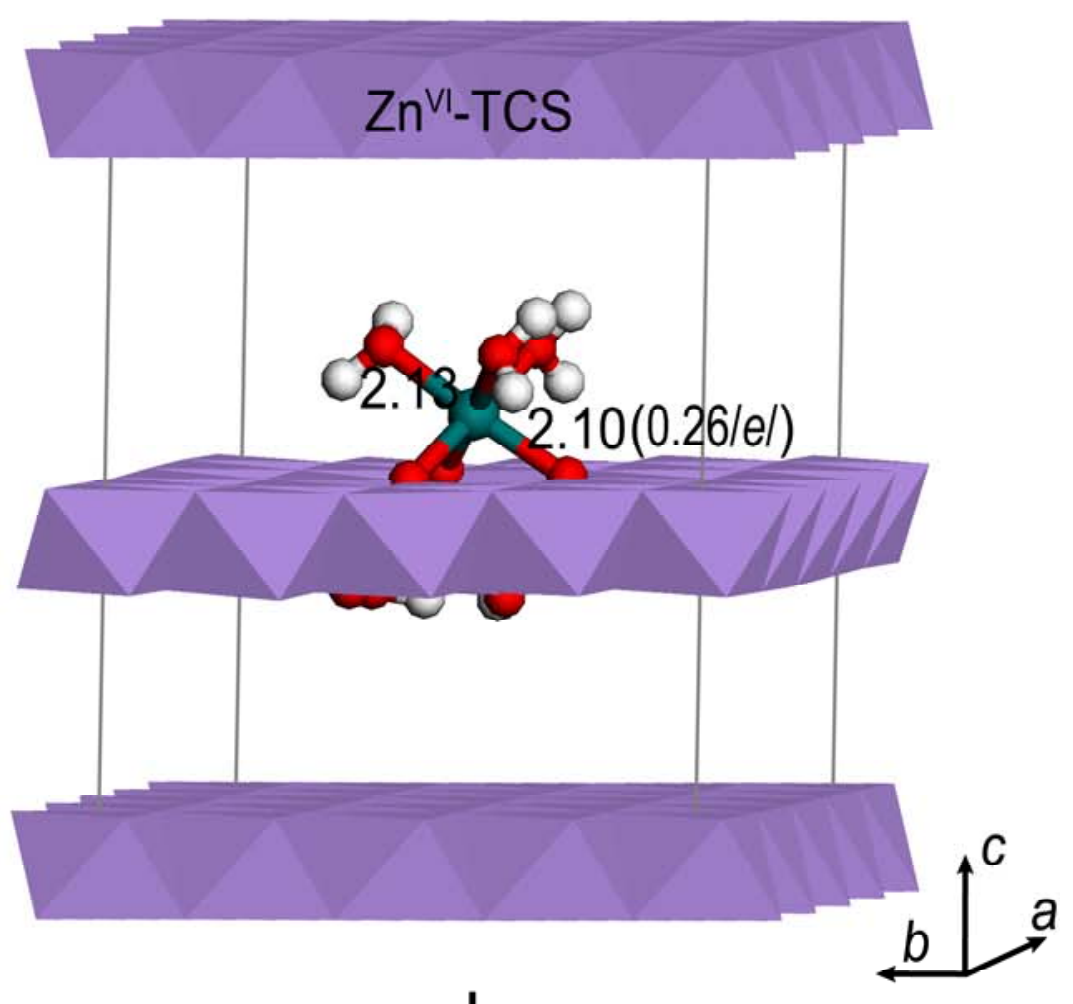

b 
Fig. 4
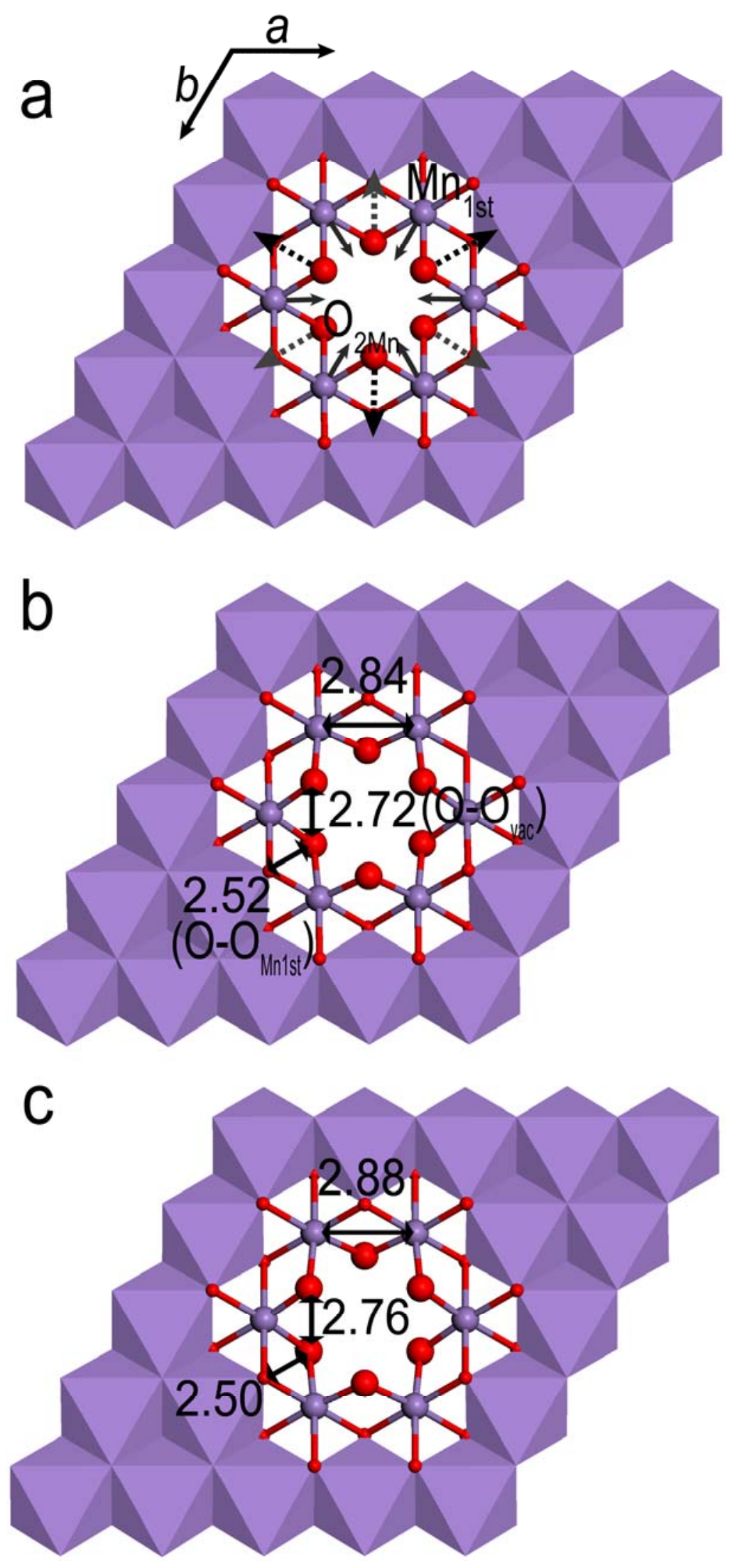
Fig. 5

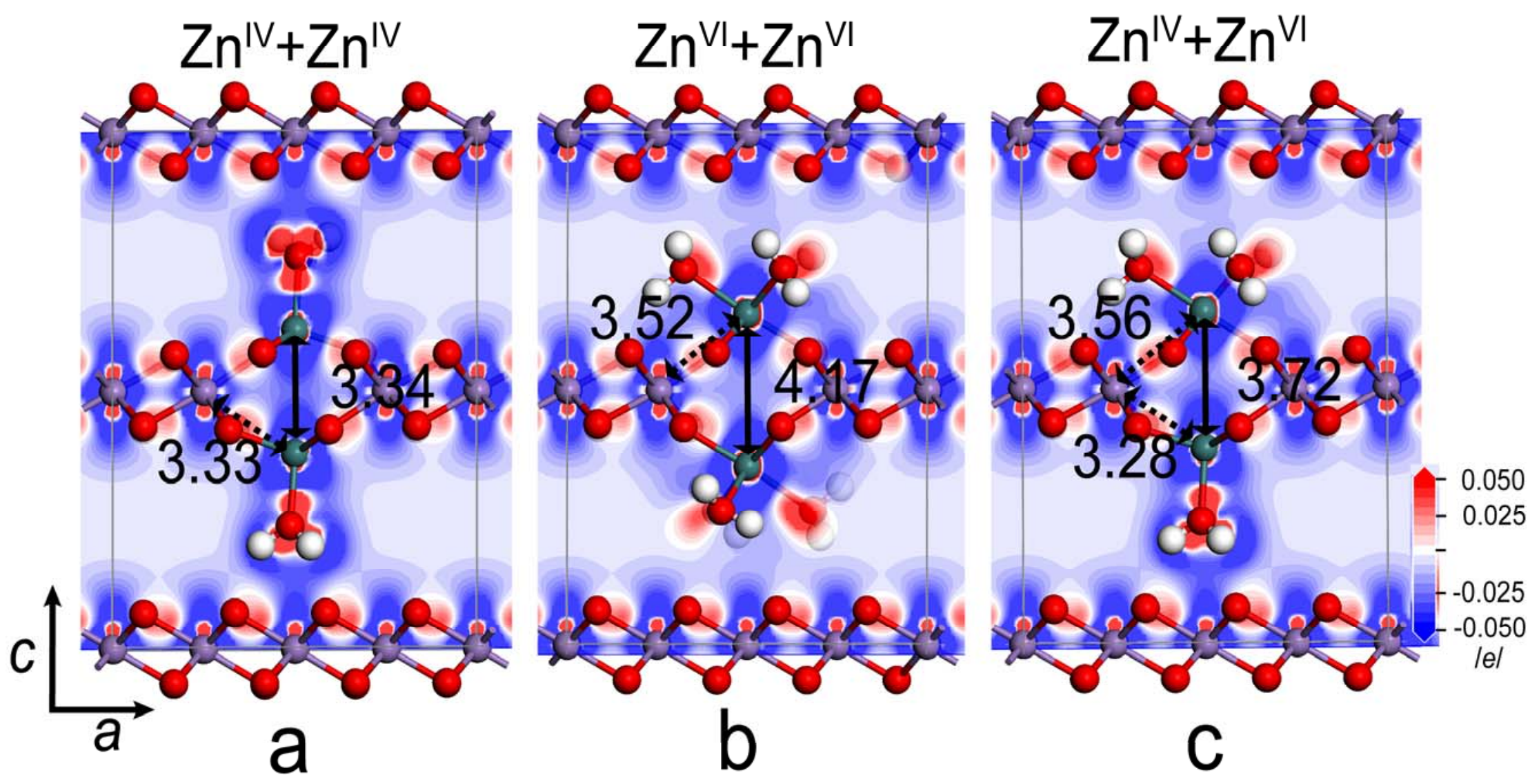


Table 1. Structural parameters for tetrahedrally-coordinated $\mathrm{Zn}\left(\mathrm{Zn}^{\mathrm{IV}}\right)$ triple-corner-sharing surface complexes in birnessite samples.

\begin{tabular}{|c|c|c|c|c|c|c|c|c|c|c|c|c|}
\hline \multirow{2}{*}{ Atom pair } & \multicolumn{2}{|c|}{$\mathrm{ZnBi}^{\mathrm{a}}$} & \multicolumn{2}{|c|}{ Marine nodule ${ }^{b}$} & \multicolumn{2}{|c|}{$\mathrm{Zn}$ biomn $1^{\mathrm{c}}$} & \multicolumn{2}{|c|}{$\mathrm{Zn} \delta-\mathrm{MnO}_{2}{ }^{\mathrm{d}}$} & \multicolumn{2}{|c|}{$6 \mathrm{KR}^{\mathrm{e}}$} & \multicolumn{2}{|c|}{ Plant roots ${ }^{\mathrm{f}}$} \\
\hline & $R(\AA)$ & $N$ & $R(\AA)$ & $N$ & $R(\AA)$ & $N$ & $R(\AA)$ & $N$ & $R(\AA)$ & $N$ & $R(\AA)$ & $N$ \\
\hline $\mathrm{Zn}-\mathrm{O}$ & 1.97 & 3.3 & $\begin{array}{c}1.96 \\
( \pm 0.02)\end{array}$ & $\begin{array}{c}4.9 \\
( \pm 1.0)\end{array}$ & $\begin{array}{c}1.97 \\
( \pm 0.01)\end{array}$ & $\begin{array}{c}4.4 \\
( \pm 0.7)\end{array}$ & $\begin{array}{c}2.07 \\
( \pm 0.02)\end{array}$ & $\begin{array}{c}5.7 \\
( \pm 1.1)\end{array}$ & n.r. & n.r. & n.r. & n.r. \\
\hline $\mathrm{Zn}-\mathrm{Mn}_{1 \mathrm{st}}$ & $3.35^{\mathrm{g}}$ & 2.9 & $\begin{array}{c}3.33 \\
( \pm 0.02)\end{array}$ & $\begin{array}{c}6.7 \\
( \pm 1.3)\end{array}$ & $\begin{array}{c}3.36 \\
( \pm 0.03)\end{array}$ & $\begin{array}{c}5.7 \\
( \pm 1.0)\end{array}$ & $\begin{array}{c}3.39 * \\
( \pm 0.02)\end{array}$ & $\begin{array}{r}1.8^{*} \\
( \pm 0.4)\end{array}$ & n.r. & n.r. & n.r. & n.r. \\
\hline
\end{tabular}

$R$ : Interatomic distance determined by EXAFS analysis; $N$ : Number of nearest-neighbor atoms; n.r.: not reported.

*Result of double-shell EXAFS analysis.

${ }^{a}$ Synthetic Zn-birnessite (Manceau et al., 2002), structure and $\mathrm{Zn}^{\text {IV }}$ content based on spectra of $\mathrm{ZnO}$ and chalcophanite.

${ }^{\mathrm{b}}$ Natural marine Zn-birnessite (Marcus et al., 2004), based on spectra of $\mathrm{ZnBi} 8^{\mathrm{a}}$ and chalcophanite.

${ }^{\mathrm{c}}$ Bacteriogenic Zn-birnessite (Toner et al., 2006), based on spectra of $\mathrm{ZnBi} 8^{\mathrm{a}}$.

${ }^{\mathrm{d}} \mathrm{Zn} \delta-\mathrm{MnO}_{2}$ (Toner et al., 2006), based on spectra of biomn $1^{\mathrm{c}}$ and chalcophanite.

${ }^{\mathrm{e}}$ Birnessite coating (Manceau et al., 2007), based on spectra of $\mathrm{ZnBi}^{\mathrm{a}}$ and marine nodule ${ }^{\mathrm{b}}$ sample.

${ }^{\mathrm{f}} \mathrm{Zn}-\mathrm{Mn}$ coprecipitate on plant roots (Lanson et al., 2008), based on spectra of $6 \mathrm{KR}^{\mathrm{e}}$, chalcophanite, and $\mathrm{Zn} \delta-\mathrm{MnO}_{2}{ }^{\mathrm{d}}$.

${ }^{\mathrm{g}}$ Result of double-shell EXAFS analysis; result of single-shell analysis is $3.37 \AA$ (Marcus et al, 2004). 
Table 2. Atomic coordinates in geometry-optimized $\mathrm{ZnMn}_{3} \mathrm{O}_{7} \cdot 3 \mathrm{H}_{2} \mathrm{O}$ (chalcophanite).

\begin{tabular}{|c|c|c|c|c|c|c|}
\hline \multirow{2}{*}{ Element } & \multicolumn{3}{|c|}{$\overline{D F T}$} & \multicolumn{3}{|c|}{$\mathrm{XRD}^{\mathrm{a}}$} \\
\hline & $X$ & $Y$ & $Z$ & $X$ & $Y$ & $Z$ \\
\hline $\mathrm{Zn}$ & 0 & 0 & 0.09779 & 0 & 0 & 0.09998 \\
\hline $\mathrm{Mn}$ & 0.71868 & 0.57786 & 0.99951 & 0.71869 & 0.57771 & 0.99948 \\
\hline $\mathrm{O} 1$ & 0.52758 & 0.62229 & 0.04566 & 0.52785 & 0.62298 & 0.04721 \\
\hline $\mathrm{O} 2$ & 0.25877 & 0.20499 & 0.04973 & 0.26078 & 0.20656 & 0.05048 \\
\hline $\mathrm{O} 3$ & 0 & 0 & 0.71235 & 0 & 0 & 0.71250 \\
\hline $\mathrm{O} 4$ & 0.17259 & 0.92092 & 0.16665 & 0.17901 & 0.93108 & 0.16435 \\
\hline $\mathrm{H} 1$ & 0.183 & 0.972 & 0.210 & $0.229^{\mathrm{b}}$ & $0.025^{\mathrm{b}}$ & $0.198^{b}$ \\
\hline $\mathrm{H} 2$ & 0.316 & 0.962 & 0.157 & $0.310^{\mathrm{b}}$ & $0.940^{\mathrm{b}}$ & $0.144^{\mathrm{b}}$ \\
\hline
\end{tabular}

O1, O3: $\mathrm{O}$ bonded to three $\mathrm{Mn}\left(\mathrm{O}_{3 \mathrm{Mn}}\right)$; O2: $\mathrm{O}$ bonded to one $\mathrm{Zn}$ and two $\mathrm{Mn}\left(\mathrm{O}_{2 \mathrm{Mn}}\right)$; O4: O of $\mathrm{H}_{2} \mathrm{O}$. The optimized cell parameters were $a=7.602 \AA$ and $c=21.349 \AA$.

${ }^{\text {a }}$ Rietveld refinement of Bisbee chacophanite whose cell parameters are $a=7.533 \AA$ and $c=$ $20.794 \AA ̊$ (Post and Appleman, 1988).

${ }^{\mathrm{b}}$ Post and Appleman (1988) calculated H coordinates using a potential-energy function evaluated at the fixed atomic positions $(\mathrm{Zn}, \mathrm{Mn}, \mathrm{O})$ of the Bisbee chalcophanite structure obtained from XRD refinement. 
Table 3. Interatomic distances $(\AA)$ in geometry-optimized isolated $\mathrm{Zn}^{\mathrm{IV}}-\mathrm{TCS}$ and $\mathrm{Zn}{ }^{\mathrm{VI}}-\mathrm{TCS}$.

\begin{tabular}{|c|c|c|c|c|c|}
\hline \multirow{2}{*}{ Atom pair } & \multicolumn{3}{|c|}{ DFT } & \multicolumn{2}{|l|}{ EXAFS $^{\mathrm{c}}$} \\
\hline & $\mathrm{Zn}^{\mathrm{IV}}$ & $\mathrm{Zn}^{\mathrm{IV}} \cdot 2 \mathrm{H}_{2} \mathrm{O}^{\mathrm{a}}$ & ${ }^{\mathrm{b}} \mathrm{Zn}^{\mathrm{VI}}$ & $\mathrm{Zn}^{\mathrm{IV}}-\mathrm{TCS}$ & $N^{\mathrm{d}}$ \\
\hline \multirow[t]{3}{*}{$\mathrm{Zn}-\mathrm{O}_{2 \mathrm{Mn}}$} & 1.94 & 1.99 & 2.10 & & \\
\hline & 1.94 & 1.98 & 2.10 & & \\
\hline & 1.95 & 1.95 & 2.12 & & \\
\hline \multirow[t]{4}{*}{$\mathrm{Zn}-\mathrm{O}\left(\mathrm{H}_{2} \mathrm{O}\right)$} & 1.99 & 1.95 & 2.13 & & \\
\hline & & & 2.13 & & \\
\hline & & & 2.16 & & \\
\hline & $<1.96>$ & $<1.97>$ & $<2.12>$ & $1.962 \pm 0.015$ & 4.9 \\
\hline \multirow[t]{7}{*}{$\mathrm{Zn}-\mathrm{Mn}_{1 \mathrm{st}}$} & 3.30 & 3.41 & 3.58 & & \\
\hline & 3.35 & 3.42 & 3.57 & & \\
\hline & 3.37 & 3.37 & 3.56 & & \\
\hline & 3.36 & 3.41 & 3.56 & & \\
\hline & 3.34 & 3.34 & 3.56 & & \\
\hline & 3.30 & 3.38 & 3.55 & & \\
\hline & $<3.34>$ & $<3.39>$ & $<3.56>$ & $3.33 \pm 0.02$ & 6.7 \\
\hline $\mathrm{Mn}-\mathrm{Mn}$ & $2.83-2.93$ & $2.82-2.94$ & $2.82-2.96$ & $2.89 \pm 0.007$ & 4.4 \\
\hline
\end{tabular}

$\mathrm{O}_{2 \mathrm{Mn}}$ : surface $\mathrm{O}$ at a vacancy site bonded to two $\mathrm{Mn} ; \mathrm{Mn}_{1 \mathrm{st}}$ : nearest $\mathrm{Mn}$ to $\mathrm{Zn}$. $N$ : number of nearest-neighbor atoms. Values in $<>$ are averages for $d(\mathrm{Zn}-\mathrm{O})$ and $d\left(\mathrm{Zn}-\mathrm{Mn}_{1 \mathrm{st}}\right)$.

${ }^{a}$ Tetrahedral Zn with H-bonding to two $\mathrm{H}_{2} \mathrm{O}$ (See Fig. 3a).

${ }^{\mathrm{b}}$ Octahedral Zn (See Fig. 3b).

${ }^{c}$ EXAFS single-shell results for marine Zn-birnessite (Marcus et al., 2004), in which octahedrally-coordinated $\mathrm{Zn}$ is at most $7 \mathrm{~mol} \%$.

${ }^{\mathrm{d}}$ Error in $N$ is $\pm 20 \%$. 
Table 4. Interatomic distances $(\AA)$ in three types of geometry-optimized, doubly-occupied Zn-TCS Mn(IV)O . $_{2}$

\begin{tabular}{|c|c|c|c|c|c|c|}
\hline \multirow{2}{*}{ Atom pair } & \multicolumn{2}{|c|}{ Tetrahedral Zn } & \multicolumn{2}{|c|}{ Octahedral Zn } & \multicolumn{2}{|c|}{ Mixed Zn } \\
\hline & $\mathrm{Zn}^{\mathrm{IV}}-\mathrm{TCS}$ & $\mathrm{Zn}^{\mathrm{IV}}-\mathrm{TCS}$ & $\mathrm{Zn}^{\mathrm{VI}}-\mathrm{TCS}$ & $\mathrm{Zn}^{\mathrm{VI}}-\mathrm{TCS}$ & $\mathrm{Zn}^{\mathrm{IV}}-\mathrm{TCS}$ & $\mathrm{Zn}^{\mathrm{VI}}-\mathrm{TCS}$ \\
\hline \multirow[t]{3}{*}{$\mathrm{Zn}-\mathrm{O}_{2 \mathrm{Mn}}$} & 1.94 & 1.94 & 2.08 & 2.09 & 1.94 & 2.09 \\
\hline & 1.94 & 1.94 & 2.10 & 2.09 & 1.94 & 2.10 \\
\hline & 1.94 & 1.94 & 2.13 & 2.12 & 1.95 & 2.13 \\
\hline \multirow[t]{4}{*}{$\mathrm{Zn}-\mathrm{O}\left(\mathrm{H}_{2} \mathrm{O}\right)$} & 1.99 & 2.00 & 2.13 & 2.13 & 2.01 & 2.13 \\
\hline & & & 2.14 & 2.13 & & 2.13 \\
\hline & & & 2.17 & 2.18 & & 2.16 \\
\hline & $<1.95>$ & $<1.96>$ & $<2.13>$ & $<2.12>$ & $<1.96>$ & $<2.12>$ \\
\hline \multirow[t]{7}{*}{$\mathrm{Zn}-\mathrm{Mn}_{1 \mathrm{st}}$} & 3.32 & 3.32 & 3.51 & 3.51 & 3.28 & 3.54 \\
\hline & 3.32 & 3.32 & 3.51 & 3.51 & 3.28 & 3.55 \\
\hline & 3.33 & 3.33 & 3.52 & 3.52 & 3.28 & 3.55 \\
\hline & 3.33 & 3.33 & 3.53 & 3.52 & 3.28 & 3.57 \\
\hline & 3.33 & 3.33 & 3.55 & 3.54 & 3.28 & 3.58 \\
\hline & 3.33 & 3.33 & 3.55 & 3.54 & 3.28 & 3.58 \\
\hline & $<3.33>$ & $<3.33>$ & $<3.53>$ & $<3.52>$ & $<3.28>$ & $<3.56>$ \\
\hline $\mathrm{Mn}_{1 \mathrm{st}}-\mathrm{Mn}_{1 \mathrm{st}}$ & \multicolumn{2}{|c|}{2.88} & \multicolumn{2}{|c|}{2.84} & $2.88^{\mathrm{a}}$ & $2.85^{\mathrm{b}}$ \\
\hline
\end{tabular}

Values in $<>$ are averages for $d(\mathrm{Zn}-\mathrm{O})$ and $d\left(\mathrm{Zn}-\mathrm{Mn}_{1 \mathrm{st}}\right)$.

${ }^{\text {a }}$ Distance between $\mathrm{Mn}_{1 \text { st }}$ octahedra whose shared $\mathrm{O}_{2 \mathrm{Mn}}$ are coordinated with $\mathrm{Zn}^{\mathrm{IV}}$-TCS

${ }^{\mathrm{b}}$ Distance between $\mathrm{Mn}_{1 \text { st }}$ octahedra whose shared $\mathrm{O}_{2 \mathrm{Mn}}$ are coordinated with $\mathrm{Zn}^{\mathrm{VI}}$-TCS 